\title{
Evidence for efficient non-evaporative leaf-to-air heat dissipation in a pine forest under drought conditions
}

\author{
Jonathan D. Muller ${ }^{1}$, Eyal Rotenberg ${ }^{1, *}$, Fyodor Tatarinov ${ }^{1}$, Itay $\mathrm{Oz}^{1}$, and Dan Yakir ${ }^{1}$ \\ ${ }^{1}$ Department of Earth and Planetary Sciences, Weizmann Institute of Science, 7610001 Rehovot, Israel \\ *Corresponding author: eyal.rotenberg@weizmann.ac.il
}

April 2021

\begin{abstract}
- Drier climates predicted for many regions can result in reduced evaporative cooling leading to leaf heat stress and enhanced mortality. To what extent non-evaporative cooling can contribute to plant resilience to the increasingly stressful conditions is poorly known at present.

- Using a novel, high accuracy infrared system for continuous measurements of leaf temperature in mature trees under field conditions, we assessed leaf-to-air temperature differences $\Delta T_{\text {leaf-air }}$ of pine needles during drought.

- On mid-summer days, $\Delta T_{\text {leaf-air }}$ remained $<1.5^{\circ} \mathrm{C}$, both in trees exposed to summer drought, and in those provided with a supplement irrigation having a $10 \times$ higher transpiration rate. The non-evaporative cooling in the drought-exposed trees must be facilitated by low resistance to heat transfer generating large $H . \Delta T_{\text {leaf-air }}$ was weakly related to variations in the radiation load and mean wind speed in the lower part of the canopy, but highly dependent on canopy structure and within-canopy turbulence that enhanced the sensible heat flux $H$.

- Non-evaporative cooling is demonstrated as an effective cooling mechanism in needle-leaf trees, which can be a critical factor in forest resistance to drying climates. The generation of a large $H$ at the leaf scale provides a basis for the development of the previously identified canopy-scale 'convector effect'.
\end{abstract}

\section{Introduction}

Plants must regulate leaf temperature to control biochemical and physiological processes, such as photosynthesis and water loss, and prevent mortality caused by temperature extremes (Still et al., 2019; Michaletz et al., 2015, 2016; Allen et al., 2010). Leaf temperature, in turn, is a function of leaf traits and environmental conditions. At equilibrium, the energy gained from incoming solar and infrared radiation is balanced by losses due to thermal radiation and latent heat fluxes, and sensible heat exchange (e.g., Gutschick, 2016; Schymanski and Or, 2016). This energy balance can be modified firstly, by leaf traits, such as its size, thickness, structure, and angle, that influence the interception of radiation (Leigh et al., 2012, 2017), and the balance between heat losses through latent and sensible heat fluxes, and secondly by environmental conditions, such as variations in sunlight, temperature, humidity, and wind speed that influence heat transfer. Describing leaf energy balance can be highly accurate under controlled conditions (Gutschick, 2016; Schymanski and Or, 2016; Michaletz et al., 2016), but can be challenging under field conditions. However, identifying the range of variations, and the limits to leaf temperature control resulting from the requirements to maintain energy balance under field conditions is critical to assess vegetation response to climate change, and to scale processes from the leaf to the canopy to ecosystem and larger scales (Still et al., 2021; Bonan, 2008).

In hot and dry ecosystems where plants operate near their limits, maintaining leaf temperature below their thermal threshold, when biochemical and 
physiological process are damaged, is critical, i.e. $41.5-50.8^{\circ} \mathrm{C}$ depending on species and climate zone (O'sullivan et al., 2017; Lancaster and Humphreys, 2020). Indeed, high temperatures can affect a variety of biophysical and biochemical processes (Still et al., 2019; Baldocchi and Penuelas, 2019) like photosynthesis, where they are associated with damage to the functioning of photosystems I \& II or the carbon reduction cycle (O'sullivan et al., 2017; Maseyk, 2006; Long et al., 1994; Werner et al., 2002), or an increased vapour pressure deficit and stomatal closure (Smith et al., 2019; Richardson et al., 2020). Not surprisingly, there has been a substantial increase in reports of drought-related tree mortality with rising air temperatures (Allen et al., 2010, 2015).

In water-limited conditions, energy absorbed from incoming radiation that is not used in photosynthesis cannot be readily dissipated through latent heat (transpiration) due to constraints on water availability. Alternatively, this heat can be dissipated through sensible heat. Indeed, semi-arid forests were shown to produce a massive sensible heat flux in spite of having a low surface to air temperature difference by lowering the aerodynamic resistance to heat transfer $\left(r_{H}\right)$ - a property called the 'canopy convector effect' that helps dissipate heat from the ecosystem to the atmospheric boundary layer under water-limiting conditions (Rotenberg and Yakir, 2010; Banerjee et al., 2017; Brugger et al., 2018; Kröniger et al., 2018; Zhang et al., 2019). Yet, understanding the evolution of this mechanism at the leaf scale and the regulation of leaf temperature has mostly been discussed in lab experiments (Tibbals et al., 1964; Gates et al., 1965; Michaletz and Johnson, 2006), but not in field conditions.

Leaf cooling through sensible heat is highly dependent on the coupling of leaves and their surrounding air. Indeed, leaf-to-air temperature difference $\left(\Delta T_{\text {leaf-air }}\right)$ is often used as a stress indicator in agricultural crops (Kim et al., 2018; Maimaitijiang et al., 2020; Zhang et al., 2019; Song et al., 2017; Long et al., 2006; Jones et al., 2009). A wide range of factors can influence the magnitude of $\Delta T_{\text {leaf-air }}$ through the heat uptake resulting from the radiation regime and non-radiative heat dissipation which is enhanced through wind penetration into the canopy layer. These factors are affected by the physical location of plants, i.e. elevation and latitude, stand density, or climatic variables such as atmospheric conditions, water supply which affects transpiration rate or large-scale wind patterns (Bonan, 2008; Still et al., 2019; Kim et al., 2016). The interplay between wind and leaf temperature is complex: on the one hand, it can increase leaf water loss because of the transport of moist air away from leaves (Schymanski and Or, 2016; McMahon et al., 2013; Neriah et al., 2014), which increases evaporative cooling. On the other hand, wind can transport sensible heat towards or away from leaves, providing an air cooling mechanism that can decrease water loss, since transpiration is a function of leaf temperature (Schymanski and Or, 2016). Overall, this mechanism is expected to be species-dependent since the reduction in resistance to sensible heat transfer through efficient air flow scales with reduced leaf dimensions (Schymanski and Or, 2016; Taylor, 1975; Geller and Smith, 1982). Indeed, leaf size, geometry and packing of leaves have been shown to be an important factor affecting leaf-to-air heat transfer due to its effect on the leaf boundary layer (Michaletz and Johnson, 2006; Schuepp, 1993; Gates et al., 1965; Tibbals et al., 1964; Schymanski and Or, 2016; Gutschick, 2016). Thin leaves such as those found in conifers have a much lower $\Delta T_{\text {leaf-air }}$ of $4-8^{\circ} \mathrm{C}$ compared to broadleaf species, where $\Delta T_{\text {leaf-air }}$ reached $10-15{ }^{\circ} \mathrm{C}$ (Kim et al., 2018; Leuzinger and Körner, 2007), even in temperate climates where the daytime air temperature rarely exceeds $25{ }^{\circ} \mathrm{C}$ (see literature value review in Table S7.1). In agricultural studies, $\Delta T_{\text {leaf-air }}$ was shown to depend on soil moisture due to the ability of plants to evaporate more water (Siebert et al., 2014). However, since the seminal work of Kim et al. (2016) on ponderosa pine canopies, few studies have followed up on climatic effects on leaf temperature on trees under field conditions, even less so in xeric ecosystems (Lapidot et al., 2019). Furthermore, we are presently unaware of any studies measuring $\Delta T_{\text {leaf-air }}$ across the height of a canopy, or comparisons between non-water-limited trees that rely on evaporative cooling versus drought-exposed trees that are limited to air-cooling in field conditions.

High precision, direct measurements of leaf temperature under field conditions are a prerequisite to extend our knowledge in this area, but they remain rare (see reviews in Still et al., 2019, 2021). This is particularly so in forests due to the vegetation height and because of the required combined measurement of leaf surface temperatures and that of the surrounding air (Kim et al., 2018). In many studies, thermocouples were used in spite of their limitations (Muller et al., 2021). Therefore, several studies have chosen infrared thermography for leaf temperature (Still et al., 2019; Jones, 2004; Fuchs, 1990). Yet, remaining challenges in using these sensors are the required calibration, knowledge of leaf emissivity 
(Richardson et al., 2020; Idso et al., 1969) and of background thermal radiation coming from all ecosystem elements (soil, plants, atmosphere). In most studies, emissivity is taken from literature values and background thermal radiation has often either been ignored or simplified using air temperature as a substitute (e.g., Birami et al., 2018), based on the assumption of a small error due to the high emissivity of natural materials $(>0.95)$, an assumption that is not always warranted (Kim et al., 2016). Alternatively, background thermal radiation has been measured using independent sensors (Aubrecht et al., 2016), or empirical correction equations were developed (Kim et al., 2018) using other environmental variables such as air temperature and/or relative humidity. Nevertheless, these methods can lead to substantial measurement errors of up to several degrees, which can be critical in assessing leaf-to-air temperature of similar magnitudes under field conditions. In many studies, air temperature was not measured in the vicinity of leaves, and previous tree canopy-scale studies generally tended to use measurements above the canopy or from nearby meteorological stations, thus amplifying the error of leaf-to-air temperature measurements.

In this study, our objectives were: (a) to measure $\Delta T_{\text {leaf-air }}$ under field conditions in needle-leaves at a high accuracy using our novel system (Muller et al., 2021); (b) to examine the spatial (across canopy height) and temporal (diurnal) variations of $\Delta T_{\text {leaf-air }}$ when evaporation is low under drought, or when it is kept high by supplemental irrigation. We hypothesized, that an efficient non-evaporative cooling mechanism at the leaf scale can help maintain low $\Delta T_{\text {leaf-air }}$, providing resilience to forests undergoing warming and drying climatic trends.

\section{Materials \& Methods}

\subsection{Site description \& meteorological measurements}

The Yatir forest research site is located in a 2800 ha afforestation of mainly Pinus halepensis trees with a height of $\sim 10 \mathrm{~m}$ in the dry southern Mediterranean region, at the northern edge of the Negev desert in Israel $\left(31^{\circ} 20^{\prime} 49^{\prime \prime} \mathrm{N} ; 35^{\circ} 3^{\prime} 7^{\prime \prime} \mathrm{E}\right.$; altitude $600-850 \mathrm{~m}$ above sea level). Tree density was 300 trees ha $^{-1}$, corresponding to $\sim 50 \%$ crown cover, and the lowest branches were at $\sim 2 \mathrm{~m}$ agl. Mean annual global radiation was $238 \mathrm{~W} \mathrm{~m}^{-2}$, while average air temperatures for January and July are 10 and $25.8^{\circ} \mathrm{C}$ respectively, with a mean annual potential ET of $1600 \mathrm{~mm}$, and mean annual precipitation of $285 \mathrm{~mm}$ (Rotenberg and Yakir, 2010; Tatarinov et al., 2016; Qubaja et al., 2019). Measurements were done during the extended dry season (June to October) typical for the semi-arid southern Mediterranean climate zone.

The research site contains an eddy covariance flux tower operating since 2000, whose above-canopy environmental sensors $\left(15 \mathrm{~m} \mathrm{agl}\right.$; air temperature $\left({ }^{\circ} \mathrm{C}\right)$, $\mathrm{RH}(\%)$, horizontal wind speed component at $18.7 \mathrm{~m}$ agl $\left(\mathrm{m} \mathrm{s}^{-1}\right)$; R3-100 3D sonic anemometer from Gill Instruments, Lymington, United Kingdom), shortwave $\left(0-4000 \mathrm{~nm}\left(\mathrm{~W} \mathrm{~m}^{-2}\right)\right.$; CM21, Kipp \& Zonen B.V., Delft, The Netherlands) and longwave radiation $\left(4-50 \mu \mathrm{m}\left(\mathrm{W} \mathrm{m}^{-2}\right)\right.$; Eppley, Newport RI) were used for auxiliary measurements of meteorological conditions during our consecutive measurement periods (Table 1) on a half-hourly timescale.

Midday conditions (10:00-14:00) were similar during the consecutive measurement periods: air temperatures were $\sim 31^{\circ} \mathrm{C}$, above-canopy incoming shortand longwave radiation were $\sim 929$ and $362 \mathrm{~W} \mathrm{~m}^{-2}$, respectively, while above-canopy wind speed averaged $3.22 \mathrm{~m} \mathrm{~s}^{-1}$ and VPD $2.72 \mathrm{kPa}$. These values, summarized in Table 1, show that conditions during summer drought remain stable and comparable, even though measurements were not taken simultaneously (i.e. the period in 2018 \& 2019 was not identical).

Finally, measurements from an experimental plot active since the spring of 2016 were available, where gas exchange chambers were used to measure assimilation and transpiration of multiple leaves on 4 twigs per chamber in $\sim 5 \mathrm{~m}$ agl in cycles of $1 \mathrm{~h}$ under summer supplemental irrigation and drought-exposed (i.e., control) conditions (Preisler, 2019). Our system was deployed to measure $T_{\text {leaf }}$ on neighbouring twigs of the 'irrigated' and 'drought-exposed' experiments (Table 1), and those simultaneous measurements were used for data analysis.

\subsection{Leaf and air temperature: Measure- ment principles}

226 227

Thermal infrared cameras record thermal radiation 228 from different sources: first, that emitted by the ob- 229 ject of interest $\left(L_{o b j}\right)$ with emissivity $\varepsilon_{o b j}$. Second, 230 the radiation of the surrounding background $\left(L_{b g}\right) \quad{ }_{231}$ that the object reflects according to $1-\varepsilon_{o b j}$ (with 232 both object and reflected radiation attenuated 233 187 188 189

\section{0} 191 192

193 194 195 196 197 198 199 200 201 202 203 204 205 206 207 208 209 210 211 212 213 214 as 216 217 218 219 220 ${ }^{24}$ $2 n$ 224 225 223

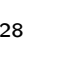 . sin

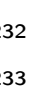


bioRxiv preprint doi: https://doi.org/10.1101/2021.02.01.429145; this version posted April 29, 2021. The copyright holder for this preprint

(which was not certified by peer review) is the author/funder, who has granted bioRxiv a license to display the preprint in perpetuity. It is made available under aCC-BY-ND 4.0 International license.

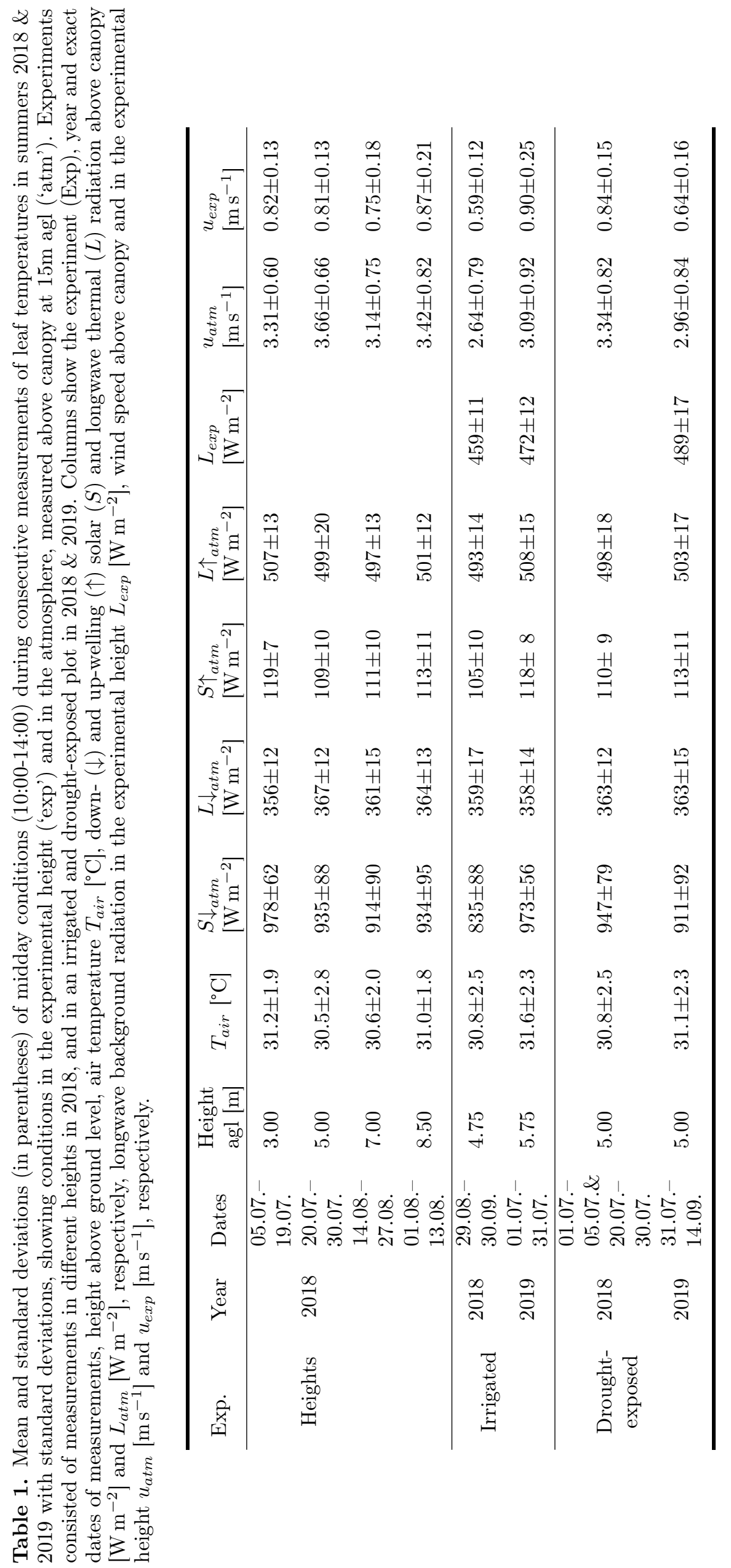


bioRxiv preprint doi: https://doi.org/10.1101/2021.02.01.429145; this version posted April 29, 2021. The copyright holder for this preprint (which was not certified by peer review) is the author/funder, who has granted bioRxiv a license to display the preprint in perpetuity. It is made available under aCC-BY-ND 4.0 International license.

PREPRINT

Muller et al., 2021

(a)
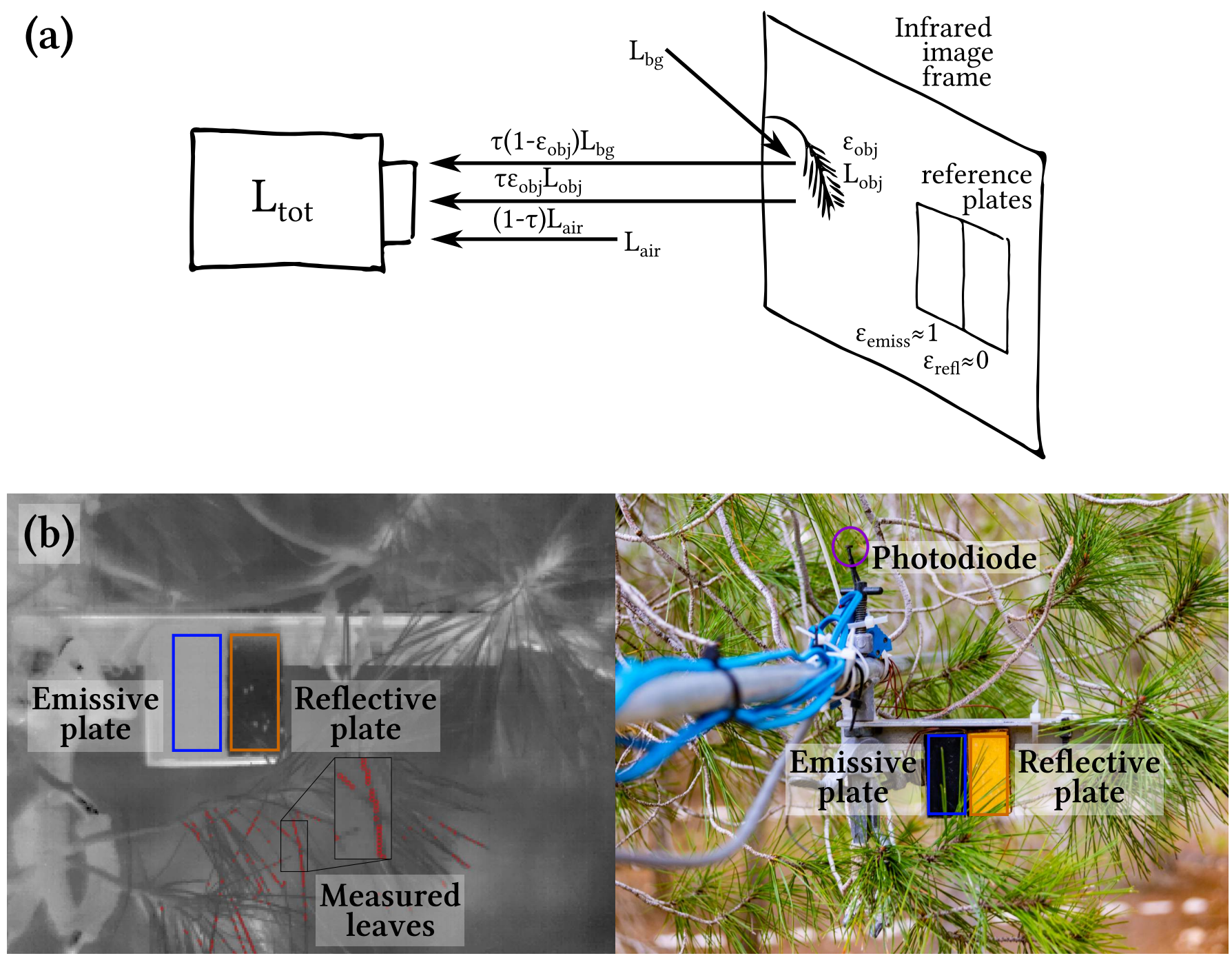

Fig. 1. (a) Illustration of the total radiation reaching an infrared camera $\left(L_{t o t}\right)$ and the relevant terms it receives, including a set of two reference plates with low $\left(\varepsilon_{\text {refl }}\right)$ and high $\left(\varepsilon_{\text {emiss }}\right)$ emissivities, respectively, in its field of view. Part of $L_{t o t}$ is emitted by the object $\left(L_{o b j}\right)$, by the air column $\left(L_{a i r}\right)$ between it and the camera which attenuates it $(\tau)$, and part is a reflection of the background $\left(L_{b g}\right)$ coming from surrounding objects and the sky. (b) Left side: Example infrared image where dark shades are colder, where red points (cf. zoomed-in square) show examples of pixels identified as leaves by automatic scripts; Right side: Setup of the infrared camera's picture frame. Polygons show the reference plates used for camera offset correction (emissive plate, blue) and background thermal radiation (reflective plate, orange) and a photodiode (purple) measured the incoming shortwave radiation.

through the air column by a transmissivity coefficient $\tau)$. Third, the thermal radiation of the air column $\left(L_{a i r}\right)$ between the sensor and the object emitting according to $1-\tau$, which is affected by the air temperature, humidity and aerosols content (Fig. 1). Hence, the total measured longwave radiation $\left(L_{t o t}\right)$ can be described by Eq. 1 (Aubrecht et al., 2016; Incropera et al., 2006; FLIR, 2011), and $\tau$ is assumed to be 1 when objects are close to the infrared camera:

$$
L_{t o t}=\tau \varepsilon_{o b j} L_{o b j}+\tau\left(1-\varepsilon_{o b j}\right) L_{b g}+(1-\tau) L_{a i r}
$$

Infrared cameras calculate the apparent object 243 temperature $\left(T_{a p}\right)$ using operator-provided fixed val- 244 ues for $\varepsilon_{o b j}, L_{b g}, L_{a i r}$ and $\tau$. When the objects (or 245 parts of them) in an infrared image have different 246 emissivities, the temperature of those pixels has to ${ }_{247}$ be adjusted. It is common practice to set the camera settings of $\varepsilon$ and $\tau$ to 1.00 to simplify corrections in post-processing. Systematic camera error can be corrected by correlating the infrared measured temperature of a reference plate with a high emissivity $\left(\varepsilon_{\text {emiss }} \approx 1\right.$; Fig. 1$)$ with its independently measured temperature (Kim et al., 2018).

In ecological applications, the background thermal radiation $L_{b g}$ has often been ignored due to the high , 248 249 250 251 253 253 254 255 256 . 252 
emissivity of natural materials and relatively small contribution of $L_{b g}$. This is sufficiently accurate where only relative temperatures are required, but can lead to substantial errors in determining the actual temperature (Kim et al., 2016). In the present study, we employed a low emissivity plate $\left(\varepsilon_{r e f l} \approx 0\right.$, Fig. 1) with an integrated thermocouple, placed in the image frame, to measure $L_{b g}$. The purpose of the embedded thermocouple is to account for the residual thermal radiation from the reflective plate observed by the thermal camera, as its emissivity is not exactly zero (Table 2). We were therefore able to measure $L_{b g}$ near the sampled object in the same spectral range as the thermal measurements according to Eq. 2:

$$
L_{b g}=\frac{L_{t o t}-\varepsilon_{r e f l} L_{r e f l}}{1-\varepsilon_{r e f l}}
$$

where $L_{t o t}$ is calculated using the Stefan-Boltzmann law $\left(L_{t o t}=\varepsilon_{c a m} \sigma T_{a p}^{4}\right)$ from the apparent temperature $\left(T_{a p}\right)$ of the reflective plate reported by the infrared camera, using the StefanBoltzmann constant $\sigma$ and the camera emissivity setting $\varepsilon_{c a m}$ (set to 1). $\varepsilon_{\text {refl }}$ is the emissivity of the highly reflective plate (Table 2) and the thermal radiation emitted by it is $L_{r e f l}=\sigma T_{r e f l}^{4}$, where $T_{r e f l}$ is the independently measured temperature of the reflective reference plate (using a calibrated thermocouple). Finally, the corrected object temperature can be calculated by applying the resulting $L_{b g}$ in Eq. 1 (Muller et al., 2021).

\subsection{Leaf and air temperature: Field measurements}

Leaf temperatures were measured during the peak of summer drought, consecutively in different heights within the canopy in summer $2018(3,5,7 \& 8.5 \mathrm{~m})$; as well as in $\sim 5 \mathrm{~m}$ (middle of the canopy) in a droughtexposed and experimentally irrigated plot in summers 2018 \& 2019 (Measurement periods \& location, cf. Table 1, map: Fig. S4.1). The mast and camera were installed and raised manually from the ground. Once extended, it was oriented so that the reference plates and photodiode would be near the leaves that were to be measured. As an unavoidable consequence, the branches in different heights were not all exactly above each other, resulting in some differences in radiative exposure of the measured leaves, as could be expected under the in-situ field conditions. In the following text, leaf temperature will refer to the mean temperature of multiple needles on the same twig (as seen in Fig. 1b).

303

304

Thermal infrared measurements of $T_{\text {leaf }}, T_{\text {emiss }}, \quad 305$ $T_{r e f l}$ and $L_{b g}$ were done using an infrared camera 306 (7.5-13 um; FLIR A320; FLIR Systems, Wilsonville, 307 Oregon, United States) facing north installed on 308 a mast, triggered automatically every 5 min (every 309 15 min before 2018-08-01) using a camera setting of 310 $\varepsilon=1.00$ and $\tau=1.00$ due to the close distance of ${ }_{311}$ $<65 \mathrm{~cm}$ between the infrared camera and the leaves 312 (setup cf. Fig. 1). Other camera parameters are 313 dropped due to $\varepsilon=1$ and $\tau=1$. At this distance, 314 pixels were $\sim 0.4 \mathrm{~mm}$ wide using a $15^{\circ}$ lens, compared 315 to a diameter of needle-leaves of $\sim 0.8-1 \mathrm{~mm}$, which 316 allowed us to avoid mixed values between the back- 317 ground (sky, branches) and the leaves (leaves). The 318 final temporal resolution was lower than 5 min be- 319 cause the camera had to be restarted every few hours 320 to circumvent crashes of the internal camera soft- 321 ware. Measurements were averaged to half hours, i.e. 322 equivalent to the typical time step for eddy covari- 323 ance flux data. An arm extending from the infrared 324 camera held branches in a fixed position to minimise 325 movement from wind and simplify image analysis. 326 Systematic camera error, i.e. the offset from the real 327 surface temperature, was corrected using measure- 328 ments of a reference aluminium plate with a highly 329 emissive coating (Metal Velvet ${ }^{T M}$ coating; Acktar 330 Ltd., Kiryat-Gat, Israel). For measurements of $L_{b g}, \quad 331$ we used a reference plate with a high reflectivity (In- 332 fragold coating; Labsphere Inc., North Sutton NH, 333 USA; installed on 2018-09-06) alongside it. Both 334 plates had a thickness of $3 \mathrm{~mm}$, and each contained 335 a thin thermocouple installed in the middle of the 336 plates, $0.5 \mathrm{~mm}$ from the coated surfaces in a tiny ${ }_{337}$ drilled hole filled with thermal grease. The plates 338 were insulated by a piece of wood $2 \mathrm{~cm}$ thick on the 339 back to prevent undesired heating from the air. Their 340 hemispherical directional emissivities (at a right angle 341 to the plates), as well as that of natural materials 342 present in Yatir forest (needle-leaves, branches, soil) 343 were measured in the lab using our special emissivity 344 measurement instrument (Vishnevetsky et al., 2019) 345 at an uncertainty of $<0.5 \%$ for an emissivity $>0.90 \quad 346$ (Table 2). Note that only mean emissivity values for 347 fresh needles are indicated, since no differences due to 348 leaf age or leaf water content could be identified (i.e. 349 difference $<0.005)$. The total temperature measure- 350 ment error of our system was $\pm 0.25^{\circ} \mathrm{C}$ (Muller et al., 351 2021), as calculated from the combined errors of each 352 sensor using the log derivative method (Fritschen 353 and Gay, 2012). This is much more accurate than 354 
bioRxiv preprint doi: https://doi.org/10.1101/2021.02.01.429145; this version posted April 29, 2021. The copyright holder for this preprint (which was not certified by peer review) is the author/funder, who has granted bioRxiv a license to display the preprint in perpetuity. It is made available under aCC-BY-ND 4.0 International license.

the previously reported IR camera accuracy of $\pm 2{ }^{\circ} \mathrm{C}$ (FLIR, 2011).

Table 2. Mean hemispherical directional emissivity with number of samples (N) and standard deviation of multiple samples of different materials measured in the lab using our custom-made system (Vishnevetsky et al., 2019). For an emissivity $\varepsilon>0.90$, the uncertainty is $\leq 0.5 \%$ of the measured $\varepsilon$, for $\varepsilon<0.95$, the uncertainty is $\leq 0.4 \%$, for $\varepsilon \leq 0.1$, the uncertainty is $\sim 28.6 \%$

\begin{tabular}{lcc}
\hline Sample Materials & $\mathrm{N}$ & Emissivity \\
\hline Branch bark & 4 & $0.896 \pm 0.014$ \\
Emissive coating; $<2018-09-06$ & 1 & 0.984 \\
Emissive coating; $>$ 2018-09-06 & 1 & 0.977 \\
Reflective coating & 1 & 0.023 \\
Pine needles (dry) & 3 & $0.933 \pm 0.010$ \\
Pine needles (fresh; 1-3 yrs old) & 4 & $0.947 \pm 0.003$ \\
Topsoil (Yatir research site) & 4 & $0.933 \pm 0.006$ \\
\hline
\end{tabular}

A photodiode sensitive in the PAR range (400700 nm; G1118, Hamamatsu Photonics K.K., Japan), calibrated against a commercial PAR sensor (PQS1, Kipp \& Zonen, Delft, The Netherlands) and a shortwave full-range pyranometer with a $0-4000 \mathrm{~nm}$ range (CM21, Kipp \& Zonen B.V., Delft, The Netherlands), was employed to measure incoming solar radiation near the leaves at $1 \mathrm{~Hz}$. The light reaching this photodiode was assumed to be the same as in the entire field of view of the thermal camera.

At a distance of $\sim 2 \mathrm{~m}$ from the measured leaves, a set of two 3D sonic anemometers (Windmaster Pro, Gill Instruments, Lymington, UK) were installed vertically ( $1.5 \mathrm{~m}$ distance from each other) on a secondary mast, where the middle point between them was at the same height as the measured leaves. Each sonic measured three components $(u, v \& w)$, from which the horizontal wind speed component (normalised to the direction and represented as $u$ from here on) and shear velocity $\left(u_{*}\right)$ were calculated at $6 \mathrm{~min}$ time steps and averaged to $1 / 2 \mathrm{~h}$ time steps (using EddyPro 7.0.6; LI-COR, Lincoln NE, USA). Then, the means of $u$ and $u_{*}$ between the two anemometers were used for further analyses. Data was logged on a field computer using a LabVIEW (National Instruments; Austin, Texas USA) software. For precise air temperature measurements, a calibrated fine Ttype thermocouples were installed in Young radiation shields (Model 41003; R. M. Young Company, Traverse City MI, USA) in the same height and on the same mast as the anemometers. Calibration of all thermocouples was done in stirred water of a known uniform temperature to remove differences of individual thermocouple junctions, as well as against a precise air temperature thermistor in a radiation

shield. The accuracy and precision of the thermocouples was $0.1{ }^{\circ} \mathrm{C}$, that of the FLIR A320 infrared camera was $\pm 1{ }^{\circ} \mathrm{C}$ and $50 \mathrm{mK}$ at $30^{\circ} \mathrm{C}$, respectively (FLIR, 2011).

392 393 394 395

\subsection{Data extraction \& outlier removal}

The high-resolution raw infrared temperature data contained in the radiometric image files captured by FLIR cameras was extracted using a custom script (Muller and Segev, 2020). Needle-leaves were then identified using local temperature minima of cold leaves compared to their blurred warmer background (Muller et al., 2021). This method was compared to manual sampling to assess its robustness (Section S1). The median and standard deviations of all the detected pixels in each category (i.e. needleleaves and reference plates) were calculated for each infrared image. Note that this provided a median temperature of needle-leaves on a twig, denoted as 'leaf' temperature.

Thermal sensors suffer from systematic sensor drift over time, and the usage of a reference plate with a high emissivity is recommended to account for this (Kim et al., 2018). This correction was performed using night-time data only $\left(R^{2}=0.99, P<.001\right.$, $R M S E=0.13^{\circ} \mathrm{C}$ ) in order to avoid the potential inaccuracy caused by temperature differences between the reference plates' surfaces and the built-in thermocouples caused by fast fluctuations of sunlight on the plates (Muller et al., 2021). Outliers resulting from sensor issues related to crashes of the infrared camera's internal software, thermocouples, dust or humidity on the reference plates leading to $> \pm 2{ }^{\circ} \mathrm{C}$ differences between both reference plate thermocouples were removed ( $<1 \%$ of data). Before the installation of the reflective plate on 2018-09-06, only the emissive plate was used to calibrate the IR camera readings of the leaf surface temperatures using a linear correlation between the built-in thermocouple and the IR reading.

\section{Results}

No effect of transpiration rates: $\Delta T_{\text {leaf-air }},{ }^{432}$ measured using the high precision temperature ${ }_{433}$ measurement system, and transpiration (TR), 434 measured using automated branch-scale gas ex- 435 change chambers, during the 2018-2019 study ${ }_{436}$ period are summarized in Figure 2. At SWR ${ }_{437}$ 428 429

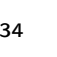
.

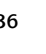
, 
bioRxiv preprint doi: https://doi.org/10.1101/2021.02.01.429145; this version posted April 29, 2021. The copyright holder for this preprint (which was not certified by peer review) is the author/funder, who has granted bioRxiv a license to display the preprint in perpetuity. It is made available under aCC-BY-ND 4.0 International license.
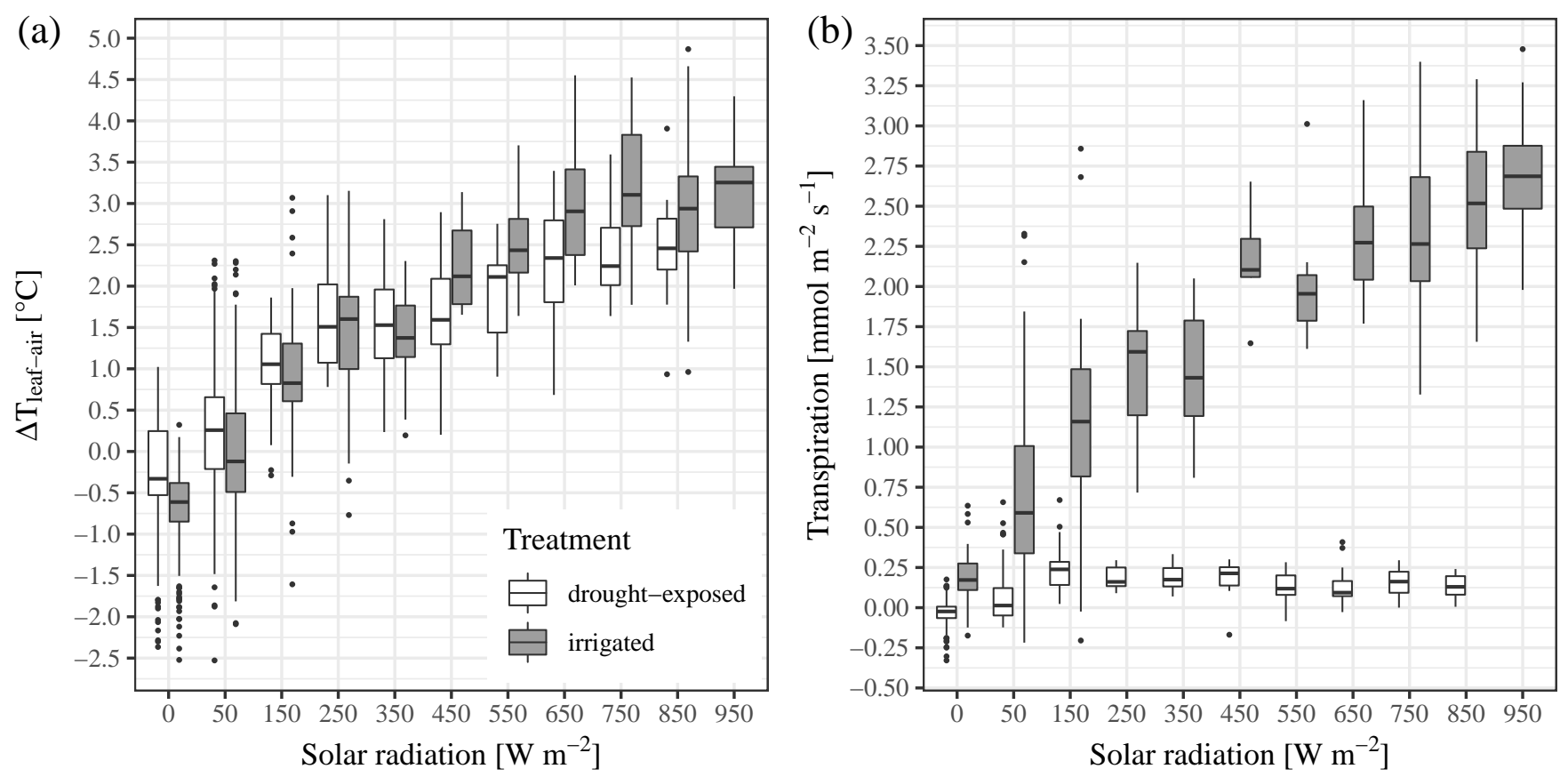

Fig. 2. Relationship between leaf-to-air temperature difference $\Delta T_{\text {leaf-air }}$ and (a) shortwave radiation, with significance of differences between treatments, and (b) transpiration in bins of SWR of $100 \mathrm{~W} \mathrm{~m}^{-2}$, measured in summers 2018 \& 2019 in irrigated (yellow) and drought-exposed trees (black) in $5 \mathrm{~m}$ agl. Bars represent standard deviations for each bin, asterisks show significance of differences between experimental treatments.

of $\quad 800-900 \mathrm{~W} \mathrm{~m}^{-2}$, TR reached maximum values of $0.12 \pm 0.07 \mathrm{mmol} \mathrm{m}^{-2} \mathrm{~s}^{-1}$ in the droughtexposed plot. This translates to a latent heat (LE) of $\sim 5 \pm 3 \mathrm{~W} \mathrm{~m}^{-2}$ under the highest SWR and net absorbed radiation levels $\left(R_{n}\right.$ of $\left.398 \pm 8 \mathrm{~W} \mathrm{~m}^{-2}\right)$. TR reached $>10 \times$ higher values of $2.34 \pm 0.67 \mathrm{mmol} \mathrm{m}^{-2} \mathrm{~s}^{-1}$ in the irrigated plots, i.e. LE $\sim 103 \pm 29 \mathrm{~W} \mathrm{~m}^{-2}$ under a similar $R_{n}$ of $\left.387 \pm 17 \mathrm{~W} \mathrm{~m}^{-2}\right) . \quad \Delta T_{\text {leaf-air }}$ values showed a clear dependence on incoming solar radiation SWR (drought-exposed: $\Delta T_{\text {leaf-air }}=$ $2.89 \exp \left(-0.006 S W R^{0.84}\right), R^{2}=0.81$; irrigated: $\left.\Delta T_{\text {leaf-air }}=3.40 \exp \left(-0.001 S W R^{1.18}\right), R^{2}=0.88\right)$, showing an approach to saturation above $600 \mathrm{~W} \mathrm{~m}^{-2}$ (Fig. 2a; see also Fig. S3.1).

The mean canopy-layer air and leaf temperatures $(\sim 5 \mathrm{~m}$ agl $)$ as well as $\Delta T_{\text {leaf-air }}$ are reported in Table 3. The results show that in spite of similar $R_{n}$ and large differences in TR, $\Delta T_{\text {leaf-air }}$ was similar on average in both plots during the day. We are particularly interested in $\Delta T_{\text {leaf-air }}$ under high radiation load (SWR $>600 \mathrm{~W} \mathrm{~m}^{-2}$ ), and as shown in Fig. 2, mean $\Delta T_{\text {leaf-air }}$ reached values of $2.4 \pm 0.6$ and $3.0 \pm 0.8^{\circ} \mathrm{C}(P<.001)$, for drought-exposed and irrigated trees, respectively. In contrast to expectations, $\Delta T_{\text {leaf-air }}$ was even slightly higher in the high transpiration irrigated plot, associated with slightly lower air temperature, which is likely due to the wetter soil below it (Table 3).

Table 3. Mean of daytime maxima (10:00-17:00) and night-time minima (21:00-05:00) of $T_{\text {leaf }}, T_{\text {air }}$ and $\Delta T_{\text {leaf-air }}$, in $\left[{ }^{\circ} \mathrm{C}\right]$

\begin{tabular}{lllll}
\hline Value & Time & $\begin{array}{l}\text { Drought- } \\
\text { exposed }\end{array}$ & Irrigated & $\mathrm{P}$ \\
\hline \multirow{2}{*}{$T_{\text {leaf }}$} & Day & $34.1 \pm 1.8$ & $32.9 \pm 2.1$ & 0.02 \\
& Night & $18.4 \pm 1.9$ & $17.8 \pm 2.1$ & 0.16 \\
$T_{\text {air }}$ & Day & $32.9 \pm 2.1$ & $32.0 \pm 2.1$ & $<.001$ \\
& Night & $18.2 \pm 1.5$ & $17.7 \pm 1.9$ & $<.001$ \\
$\Delta T_{l-a}$ & Day & $2.5 \pm 0.7$ & $2.5 \pm 1.4$ & 0.96 \\
& Night & $-0.7 \pm 0.8$ & $-1.2 \pm 0.6$ & $<.001$ \\
\hline
\end{tabular}

A significant relationship between $\mathrm{TR}$ and 467 $\Delta T_{\text {leaf-air }}$ was exhibited in irrigated trees (Fig. $2 \mathrm{~b} ; 468$ $\left.\Delta T_{\text {leaf-air }}=-0.97+1.61 T R, R^{2}=0.96, P<.001\right), \quad 469$ but not in drought-exposed trees where $\Delta T_{\text {leaf-air }} \quad 470$ increased to similar levels, but with a near lack of ${ }_{471}$ transpiration (Figure $2 \mathrm{~b} ; R^{2}=0.01, P=0.78$ ). The 472 increase of $\Delta T_{\text {leaf-air }}$ seems to be largely driven 473 by SWR, which also drives the increases in TR in 474 irrigated trees. Therefore, the remarkably similar 475 maximum $\Delta T_{\text {leaf-air }}$ value was observed in the two 476 treatments in spite of the $\sim 10 \times$ difference in TR ${ }_{477}$ values. This indicated that evaporative cooling in 478 itself does not prevent leaf heating (i.e., $\Delta T_{\text {leaf-air }} \quad 479$ increased in spite of large increase in TR; Fig. 2b). 480 
bioRxiv preprint doi: https://doi.org/10.1101/2021.02.01.429145; this version posted April 29, 2021. The copyright holder for this preprint (which was not certified by peer review) is the author/funder, who has granted bioRxiv a license to display the preprint in perpetuity. It is made available under aCC-BY-ND 4.0 International license.
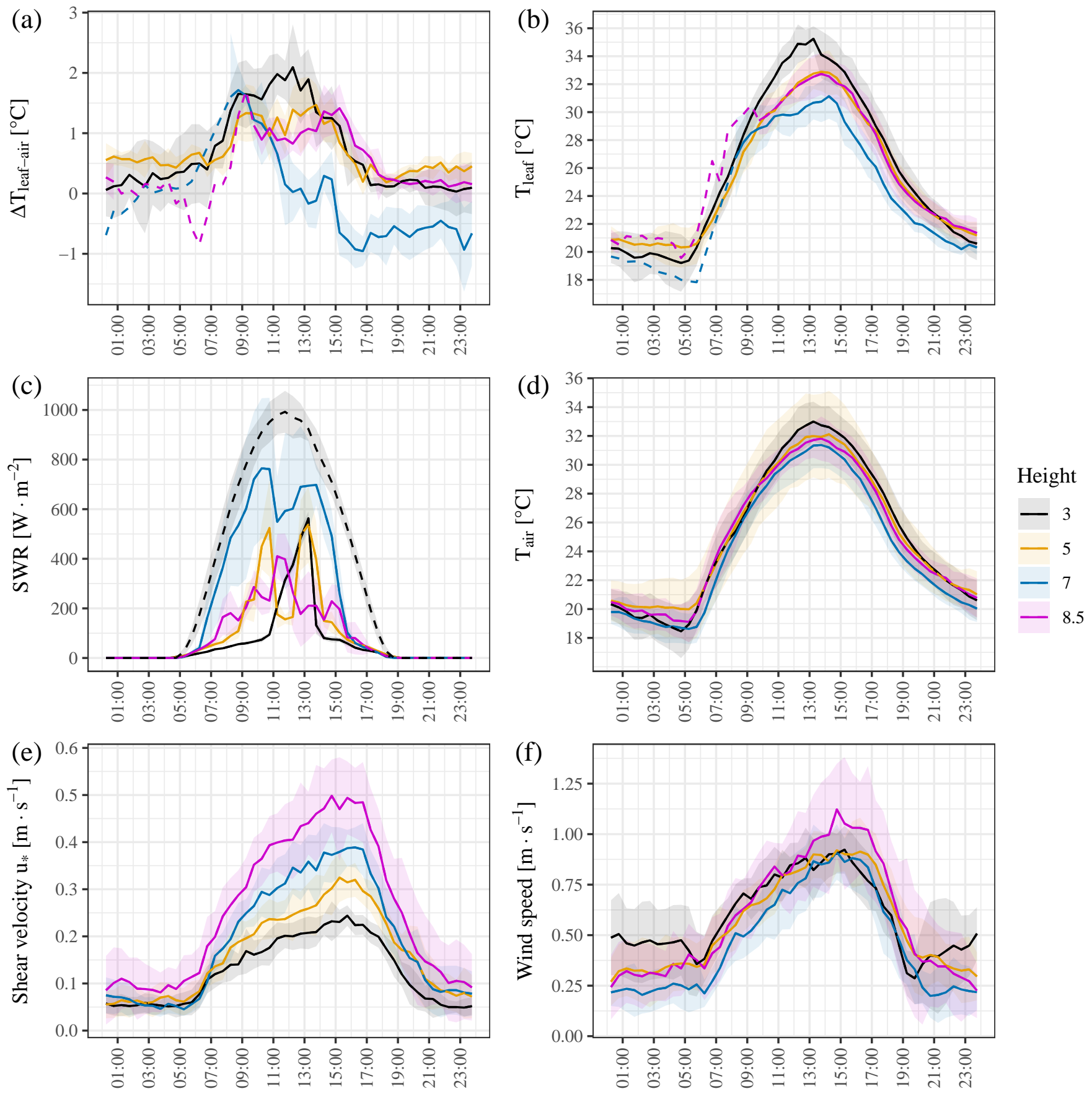

Fig. 3. Diurnals of half-hourly means over 2 weeks in the drought-exposed plot of (a) leaf-to-air temperature difference $\Delta T_{\text {leaf-air }}\left[{ }^{\circ} \mathrm{C}\right]$, (b) leaf temperature $T_{\text {leaf }}\left[{ }^{\circ} \mathrm{C}\right],(\mathrm{c})$ incoming shortwave radiation SWR $\left[\mathrm{W} \mathrm{m}^{-2}\right]$ with above-canopy SWR (dashed black), (d) air temperature $T_{\text {air }}\left[{ }^{\circ} \mathrm{C}\right]$, (e) shear velocity $u_{*}\left[\mathrm{~m} \mathrm{~s}^{-1}\right]$, (f) wind speed $u\left[\mathrm{~m} \mathrm{~s}^{-1}\right]$. Colours represent different heights in the canopy (i.e. $3,5,7 \& 8.5 \mathrm{~m}$ agl), solid lines depict times with more than 3 available observations and shade is standard deviation, dashed lines have 1-2 observations (due to repeated camera failure). 
bioRxiv preprint doi: https://doi.org/10.1101/2021.02.01.429145; this version posted April 29, 2021. The copyright holder for this preprint (which was not certified by peer review) is the author/funder, who has granted bioRxiv a license to display the preprint in perpetuity. It is made available under aCC-BY-ND 4.0 International license.

\section{Factors affecting leaf to air temperature dif-} ferences: $\Delta T_{\text {leaf-air }}$ and the factors that can influence it were examined in more detail in the droughtexposed, i.e. control, plot and are summarized in Fig. 3. Shortwave radiation measurements (SWR) highlight the differences in shading in the different heights (Fig. 3c), which was associated with the orientation of the mast and the complex canopy structure in this field study. Therefore, the infrared camera measured more exposed leaves of the exposed outer parts of the canopy ('canopy skin') at $7 \mathrm{~m}$, where SWR levels were similar to the ones above canopy (up to $\sim 1000 \mathrm{~W} \mathrm{~m}^{-2}$ ). At $3,5 \& 8.5 \mathrm{~m}$, canopy shading reduced mean SWR input to a maximum $1 / 2 \mathrm{~h}$ mean of $550 \mathrm{~W} \mathrm{~m}^{-2}$.

Leaf-to-air temperature differences $\left(\Delta T_{\text {leaf-air }}\right.$, Fig. 3a, c) did not simply follow variations in SWR. For example, $\Delta T_{\text {leaf-air }}$ remained below $2.5^{\circ} \mathrm{C}$, and on average below $2{ }^{\circ} \mathrm{C}$ at $3 \mathrm{~m}$ and below $1.5^{\circ} \mathrm{C}$ at $8.5 \mathrm{~m}$ in spite of similar levels of SWR $\left(<550 \mathrm{~W} \mathrm{~m}^{-2}\right)$. Variations in $T_{\text {leaf }}$ mostly paralleled air temperature $\left(T_{\text {air }}\right)$, but mostly remained above it (Fig. 3d). However, after 9:00 at $5 \mathrm{~m}$ and $7 \mathrm{~m}$, the increase in $T_{\text {leaf }}$ slowed down below the rate of increase of $T_{\text {air }}$ (Fig. 3b, d), leading to a stabilisation or even decrease of $\Delta T_{\text {leaf-air }}$ even though SWR, $T_{\text {leaf }}$ and $T_{\text {air }}$ were still rising. In the exposed leaves at $7 \mathrm{~m}$, this decrease even led to negative $\Delta T_{\text {leaf-air }}$ of up to $-1^{\circ} \mathrm{C}$ at the time of maximum $u_{*}$ and dropping SWR input around 15:00. Note that LWR at these exposed leaves was on average $-40 \mathrm{~W} \mathrm{~m}^{-2}$ all day (i.e. radiative cooling). Against expectations, $\Delta T_{\text {leaf-air }}$ was highest at the bottom of the canopy $(3 \mathrm{~m})$ where it increased by $\sim 1.5{ }^{\circ} \mathrm{C}$ following sunrise, in spite of low SWR $\left(<100 \mathrm{~W} \mathrm{~m}^{-2}\right)$. Furthermore, the independence of variations in $T_{\text {leaf }}$ from those in SWR was especially clear in this canopy layer $(3 \mathrm{~m})$, where the stabilisation of $\Delta T_{\text {leaf-air }}$ at $\sim 2{ }^{\circ} \mathrm{C}(9: 00-13: 00)$ occurred before the peak of solar radiation (13:0014:00)

Mean half-hourly wind speed $(u)$ was not significantly different between different heights during daytime (At 11:15 and 15:45, $P>.05$; Fig. 3f). However, daytime turbulence (indicated using shear velocity $u_{*}$ ) did differ significantly between heights $(P<.05)$, resulting from the interactions of wind speed and the canopy structure. For instance, $u_{*}$ was highest at the top of the canopy $\left(0.5 \mathrm{~m} \mathrm{~s}^{-1}\right.$; Fig. 3e). At $5,7 \& 8.5 \mathrm{~m}$, the daily course of $\Delta T_{\text {leaf-air }}$ closely followed that of $T_{\text {air }}$ and turbulence: With $u_{*}<0.25$ $\mathrm{m} \mathrm{s}^{-1}, \Delta T_{\text {leaf-air }}$ increased with $T_{\text {air }}$, but quickly decreased above this threshold. At $3 \mathrm{~m}, u_{*}$ remained below $0.25 \mathrm{~m} \mathrm{~s}^{-1}$ throughout the day, and $\Delta T_{\text {leaf-air }} \quad 533$ remained high and appeared decoupled from $u_{*}$. In 534 summary, our results do not show a direct depend- 535 ence of $\Delta T_{\text {leaf-air }}$ on SWR and wind speed, but 536 indicate more likely effects of that of the daily course ${ }_{537}$ of $T_{\text {air }}$ and $u_{*}$.

\section{Discussion}

Non-evaporative vs. evaporative cooling: Leaf 540 thermal regulation has been shown across a wide 541 range of ecosystems (Michaletz et al., 2016). It is 542 commonly assumed that evaporative cooling through 543 transpiration (TR) is the most effective heat dissipa- ${ }^{544}$ tion mechanism (Wulfmeyer et al., 2014) and is key 545 to optimize leaf temperature for the leaf biochemical 546 processes (Dusenge et al., 2019). Evaporative cooling 547 can result in a temperature reduction of up to $9{ }^{\circ} \mathrm{C}$ in $\quad{ }_{548}$ broadleaf species (Urban et al., 2017). Furthermore, 549 leaf temperature and $\Delta T_{\text {leaf-air }}$ provide an indicator 550 of evaporative cooling, where warmer leaves indicate 551 stomatal closure, more stress, and reduced gas ex- 552 change (e.g., Leuzinger and Körner, 2007; Kim et al., 553 2018). Evaporative cooling can also reflect the effects 554 of other interacting factors that influence stomatal 555 conductance, such as VPD (Kimball and Bernacchi, 556 2006), or rising $\mathrm{CO}_{2}$ levels (Urban et al., 2017; Kim- 557 ball and Bernacchi, 2006; Leakey et al., 2006; Long 558 et al., 2006). Similarly, the effect of climate driven 559 rise in temperatures on leaf assimilation and water 560 loss will depend on the effects of concurrent changes 561 in factors such as VPD and atmospheric $\mathrm{CO}_{2}$ on ${ }_{562}$ leaf conductance, evaporation and, ultimately, leaf 563 temperature (Dusenge et al., 2019; Kirschbaum and 564 McMillan, 2018).

Our results indicated deviations from the common $\Delta T_{\text {leaf-air }}$ dependency on transpiration and stomatal conductance, as reflected in the similar $\Delta T_{\text {leaf-air }}$ in leaves with an order of magnitude difference in leaf transpiration. As discussed below, this can be achieved by changes in the leaf sensible heat flux, that must reflect changes in the leaf resistance to heat transport, which could be associated, in turn, with the small anatomical, structural and spectral differences observed between the leaves of droughtexposed and irrigated trees.

We observed that transpiration at the highest radiation bin (SWR $\sim 800-900 \mathrm{~W} \mathrm{~m}^{-2}$, Fig. 2) translates to a latent heat $\mathrm{LE}$ of $\sim 5 \mathrm{~W} \mathrm{~m}^{-2}$ in the droughtexposed, and $10 \times$ times higher value of $\sim 103 \mathrm{~W} \mathrm{~m}^{-2}$

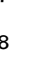

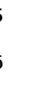


bioRxiv preprint doi: https://doi.org/10.1101/2021.02.01.429145; this version posted April 29, 2021. The copyright holder for this preprint (which was not certified by peer review) is the author/funder, who has granted bioRxiv a license to display the preprint in perpetuity. It is made available under aCC-BY-ND 4.0 International license.

in the irrigated trees. This reflects a major change in the leaf energy budget, which can be described as:

$$
R_{n}=H+L E+G+B
$$

where $R_{n}$ is the net radiation, and $G$ and $B$ are net physical heat storage and energy taken up by biochemical reactions, which are typically considered negligible (Schymanski et al., 2013). $R_{n}$ in the two study plots was calculated from the net shortwave (using absorptance of 0.46; based on Hosgood et al., 1995) and longwave components $\left(L_{n}=L_{b g}-\varepsilon_{\text {leaf }} \sigma T_{\text {leaf }}^{4}\right) . R_{n}$ in the two study plots had similar mean values of $398 \pm 8 \mathrm{~W} \mathrm{~m}^{-2}$ and $387 \pm 17 \mathrm{~W} \mathrm{~m}^{-2}$ in the drought-exposed and irrigated plots, respectively, for the highest SWR bin $\left(\sim 800-900 \mathrm{~W} \mathrm{~m}^{-2}\right.$, Fig. 2). With measured values of $R_{n}$ and LE, and negligible effects of $G$ and $B$ in Eq. 3, the leaf energy budget can only be adjusted via the sensible heat flux $\mathrm{H}$. This, in turn, indicates a requirement for a large difference in $\mathrm{H}$ in the order of $\sim 108 \mathrm{~W} \mathrm{~m}^{-2}$ between the drought-exposed $\left(H \approx 392 \mathrm{~W} \mathrm{~m}^{-2}\right)$ and irrigated $\left(H \approx 284 \mathrm{~W} \mathrm{~m}^{-2}\right)$ trees. The sensible heat flux can, in turn, be described by:

$$
H=\rho c_{p} \frac{\Delta T_{\text {leaf-air }}}{r_{H}}
$$

where $c_{p}$ and $\rho$ are the heat capacity and density of air surrounding the leaves, and $r_{H}$ is the leaf resistance to heat transfer (where 'leaf' denotes multiple needles on a small twig; see Methods). Note that a simple sensitivity test indicates that a difference of $15 \mathrm{mmol} \mathrm{mol}^{-1}$ in air moisture or $5{ }^{\circ} \mathrm{C}$ in air temperature (when ambient $T_{\text {air }}$ is $\sim 30^{\circ} \mathrm{C}$ ) near leaves would produce a change in $H$ of $\sim 2.5^{-}$ $10 \mathrm{~W} \mathrm{~m}^{-2}$ due to changes $c_{p}$ and $\rho$. Assuming, for a first approximation, that differences in air $c_{p}$ and $\rho$ between the nearby plots were negligible, the difference in $H$ derived above for the control and irrigated leaves, requires a proportional change in $r_{H}$, (i.e. $392 / 284=1.38)$. In other words, under similar $R_{n}$ conditions, the efficient non-evaporative cooling observed in the control leaves must involve $>30 \%$ decrease in $r_{H}$.

\section{Factors contributing to change in resistance} to heat exchange at the leaf scale: Adaptation in plants has optimised leaf shapes and distribution for thermal regulation (Michaletz et al., 2016) and convective cooling (Smith, 1978). This can hap- pen through an enhanced air flow and reduced $r_{H}, \quad 625$ while concurrently minimizing its negative effects on 626 evaporative water loss (Schymanski and Or, 2016; 627 Grace and Wilson, 1976). Leaf and branch resist- ${ }_{628}$ ance to heat dissipation and the production of $\mathrm{H}{ }_{629}$ is affected by factors that mainly modify the leaf 630 boundary layer size or the flow of air surrounding the 631 leaves. Often, $r_{H}$ has been parametrised using air 632 flow variables measured above the canopy, i.e. wind 633 speed u (Jones, 2004; Kool et al., 2016; Kustas and 634 Norman, 1999; Verma, 1989) and shear velocity $u_{*} \quad 635$ (Baldocchi and Ma, 2013; Liu et al., 2007), which 636 indicates an increased local turbulence. Addition- 637 ally, there are numerous reports of leaf anatomical, 638 structural, and surface effects on convective cooling 639 (Michaletz et al., 2016). For example, Leigh et al. 640 $(2012,2017)$ demonstrate clear relationships between ${ }_{641}$ $\Delta T_{\text {leaf-air }}$ and leaf shape and thickness, resulting 642 in a $\Delta T_{\text {leaf-air }}$ range of $2-10^{\circ} \mathrm{C}$. These studies also ${ }_{643}$ indicate the trade-offs between the leaf heat capa- ${ }^{644}$ city that helps to deal with fast intense radiation 645 exposure fluctuations (Schymanski et al., 2013), and 646 the leaf size required to reduce $r_{H}$. Leaf surface ${ }_{647}$ structures such as veins or hairs also affect roughness 648 and therefore the generation of turbulence, which 649 can improve convective cooling, as does leaf orient- 650 ation relative to the wind direction (Schuepp, 1993; 651 Grace and Wilson, 1976; Grace et al., 1980) or leaf 652 spreading, as shown through the higher $\Delta T_{\text {leaf-air }}{ }_{653}$ of densely packed needle-leaves (Smith and Carter, ${ }_{654}$ 1988). Needle-leaves, such as used in this study, may 655 be a good example of low resistance leaves, based 656 on their shape and surface to volume ratio, which 657 all minimise the size of the boundary layer while 658 maintaining sufficient leaf heat capacity.

Within the same species and at the same site, large changes in leaf and branch $r_{H}$ are more difficult to explain. But as argued above, the drought-exposed and irrigated trees must also exhibit some adjustments that produce large differences in $r_{H}$ between them. Indeed, preliminary observations indicated some changes in leaf/twig characteristics, resulting from the summer supplement irrigation. As a result, in the drought-exposed plot, needle-leaves were significantly shorter (and slightly but not significantly thicker), had a reduced clumpiness (needle density per twig), and lower chlorophyll content (Section S7, Figs. S5.1, S5.2 and S6.1). Shorter leaves and reduced packing are consistent with reduced $\Delta T_{\text {leaf-air }}$ (Smith and Carter, 1988) and thus $r_{H}$ in different plant species, as a result of simple vs. complex leaves that allow for more efficient air flow (Leigh et al., 2017). Early studies already noted the importance 
bioRxiv preprint doi: https://doi.org/10.1101/2021.02.01.429145; this version posted April 29, 2021. The copyright holder for this preprint (which was not certified by peer review) is the author/funder, who has granted bioRxiv a license to display the preprint in perpetuity. It is made available under aCC-BY-ND 4.0 International license.

of leaf dimensions (e.g., Monteith, 1973; Landsberg and Thom, 1971; Gates, 1962 or packing of leaves (Michaletz and Johnson, 2006; Landsberg and Thom, 1971; Grant, 1984) in estimating the leaf boundary layer resistance to heat transfer $r_{H}$. Hence, the observed change in leaf packing in our study (Section S7; Fig. S6.1) could indeed lead to a sufficient reduction in $r_{H}$ associated with changes in leaf boundary layer turbulence (Michaletz and Johnson, 2006). Additionally, the reduced pigment concentration under dry conditions (Section S7) could help in reducing leaf heating and increased reflectivity. Such effects could support the observed lack in $\Delta T_{\text {leaf-air }}$ differences, but this should be explored further in future work.

Clearly, the detailed estimation of changes in leaf resistance to heat dissipation requires, and justifies, further research. However, the available information provides strong supporting evidence to the hypothesis that significant changes in $r_{H}$ within the same species and location are possible under different soil moisture conditions. These conclusions, in turn, support the idea that efficient non-evaporative cooling can be developed in pine trees under dry conditions, based on a reduced $r_{H}$ and the generation of a large $\mathrm{H}$. This results in a low $\Delta T_{\text {leaf-air }}$ similar to that of high transpiration leaves that rely on a combination of higher $r_{H}$ and higher TR to maintain a low $\Delta T_{\text {leaf-air }}$

Linking leaf temperature to canopy structure and turbulence: While the importance of surface roughness and structure is seldom considered at the leaf scale, such effects have been clearly demonstrated at the ecosystem scale (Rotenberg and Yakir, 2010, 2011). Sparse canopies, such as in our opencanopy forest, allow for the penetration of wind and efficient heat exchange through a higher roughness and reduced canopy-scale $r_{H}$ (Banerjee et al., 2017; Eder et al., 2015). In our conditions, this could reduce leaf temperatures to within $2{ }^{\circ} \mathrm{C}$ of the air. The vegetation type (conifers vs. broadleaves) and the observation point (top vs. within canopy) can also contribute to the range of observed canopy-air temperature differences of $-2{ }^{\circ} \mathrm{C}$ to $10^{\circ} \mathrm{C}$ (Table S7.1). Note that our use of non-aspirated radiation shields for air temperature measurements could lead to an overestimation of $\Delta T_{\text {leaf-air }}$ during daytime due to the effect of solar radiation, but the specific effect of such shields is likely to be small and with a similar effect in the different treatments. Such effects remain a matter of discussion in the literature (e.g., Kurzeja, 2009).
Our measurements of needle-leaf temperature in different heights of the canopy with distinct shading regimes showed that higher mean SWR does not always translate to a high $\Delta T_{\text {leaf-air }}$. Instead, $T_{\text {leaf }}$ generally paralleled $T_{\text {air }}$ during most of the day (Fig. 3b,d). In some periods, such as during the 9:00 to 14:00 period, the increase of $T_{\text {leaf }}$ fell below that of $T_{a i r}$, hence $\Delta T_{\text {leaf-air }}$ no longer increased. Furthermore, at the bottom of the canopy $(3 \mathrm{~m} \mathrm{agl})$ where SWR remained below $550 \mathrm{~W} \mathrm{~m}^{-2}$, $\Delta T_{\text {leaf-air }}$ reached $2{ }^{\circ} \mathrm{C}$ throughout the day, while in the exposed upper part of the canopy $(7 \mathrm{~m})$, $\Delta T_{\text {leaf-air }}$ dropped to $\sim 0^{\circ} \mathrm{C}$ in spite of high SWR of $\sim 800 \mathrm{~W} \mathrm{~m}^{-2}$. Clearly, the results reflect complex interactions between $T_{\text {leaf }}, T_{\text {air }}$ and SWR, but it also indicated a more tight relationship between $T_{l e a f}$ and $T_{a i r}$ than with SWR. Note also that $T_{l e a f}$ and $T_{a i r}$ at the bottom of the canopy are strongly affected by the soil temperature. In our example of a low density forest, SWR heats up a significant fraction of exposed ground, resulting in the production of large thermal radiation and sensible heat flux that heat up the bottom of the canopy, in what was previously described as a 'canopy greenhouse effect' (Rotenberg and Yakir, 2011).

In addition to the unexpectedly ambiguous effects of SWR on leaf temperature, the effects of wind speed and in turn, turbulence, can be at least as important. At the study site, wind speed was not directly correlated with $\Delta T_{\text {leaf-air }}$ (Fig. 3), but the decrease of $\Delta T_{\text {leaf-air }}$ with height coincided with the magnitude of turbulence, described using shear velocity $u_{*}$ (Fig. 3a,e). Indeed, with $u_{*}<0.25 \mathrm{~m} \mathrm{~s}^{-1}, \Delta T_{\text {leaf-air }}$ either increased or remained nearly constant, but decreased above this threshold. This explains the suppression of the expected high $\Delta T_{\text {leaf-air }}$ to $\sim 0{ }^{\circ} \mathrm{C}$ at the top of the canopy $(8.5 \mathrm{~m})$, while it reached $\sim 2{ }^{\circ} \mathrm{C}$ at the bottom $(3 \mathrm{~m})$ where turbulence was low $\left(u_{*}<0.25 \mathrm{~m} \mathrm{~s}^{-1}\right)$.

These results provide an opportunity to explain the $\Delta T_{\text {leaf-air }}$ distribution across the canopy (Fig. 4), particularly in forests with a low stand density such as ours where turbulence creates an efficient air flow within the canopy layer. As noted above, at the bottom of the canopy $(3 \mathrm{~m} \mathrm{agl})$ the combination of the lowest turbulence and the heating from the ground results in the highest $\Delta T_{\text {leaf-air }}$ of $2^{\circ} \mathrm{C}$ (Fig. 3). Indeed, this 'canopy greenhouse effect' led to a comparable net radiation both above and within the canopy at the same research site (Rotenberg and Yakir, 2011), and therefore to a similar amount of heat to be dissipated. In exposed leaves at $7 \mathrm{~m}$ (mean 
bioRxiv preprint doi: https://doi.org/10.1101/2021.02.01.429145; this version posted April 29, 2021. The copyright holder for this preprint (which was not certified by peer review) is the author/funder, who has granted bioRxiv a license to display the preprint in perpetuity. It is made available under aCC-BY-ND 4.0 International license.

1/2h SWR: $\left.\sim 800 \mathrm{~W} \mathrm{~m}^{-2}\right), \Delta T_{\text {leaf-air }}$ rapidly dropped from $\sim 2{ }^{\circ} \mathrm{C}$ to $\sim 0{ }^{\circ} \mathrm{C}$ by noon due to the high turbulence generated from the interaction of the typical regional sea breeze with the roughness of the forest canopy and in spite of a high air temperature. After 15:00, $\Delta T_{\text {leaf-air }}$ even dropped below $\sim 0^{\circ} \mathrm{C}$ in this height. It seems plausible that this is a result of the more dominant radiative cooling when incoming SWR sharply drops (negative net longwave radiation on average $-40 \mathrm{~W} \mathrm{~m}^{-2}$ at this position), and slow decrease in TR at this time (see Qubaja et al., 2020). Such height dependence variations in the $\Delta T_{\text {leaf-air }}$ dynamics clearly reflect the complexity of the ambient conditions across the canopy under field conditions. Finally, $\Delta T_{\text {leaf-air }}$ of shaded leaves near the top of the canopy $(8.5 \mathrm{~m})$ was suppressed all day long and remained around $\sim 1{ }^{\circ} \mathrm{C}$. These leaves seemed to benefit from the combined effects of shading, the low incoming LWR from the cold atmosphere (as compared to LWR from the soil in the lower canopy), and maximal turbulence, which increases air-cooling through an increased turbulent air flow.

The apparent contrast between the near-top and bottom of the canopy demonstrates the importance of turbulence within the canopy in controlling $\Delta T_{\text {leaf-air }}$, which relies on the reduced leaf-scale $r_{H}$ resulting from anatomical and biophysical adjustments. This efficient turbulent air cooling of leaves helps trees to survive the long summer drought (Tatarinov et al., 2016) and improves $\mathrm{CO}_{2}$ assimilation during the few optimal hours of the day (Maseyk et al., 2008; Michaletz et al., 2015). Indeed, leaf temperatures were kept below $40^{\circ} \mathrm{C}$ at our site in high summer, which is considered the temperature of biochemical and physical damage to the photosynthetic apparatus (e.g., O'sullivan et al., 2017; Lancaster and Humphreys, 2020). The heat dissipated from leaves to their surrounding air can be subsequently transported to the atmosphere through turbulent wind penetration into the canopy layer. This has implications for the development of the large sensible heat flux out of the forest canopy, such as described by (Banerjee et al., 2017) as a basis of the generation of the so called canopy 'convector effect'.

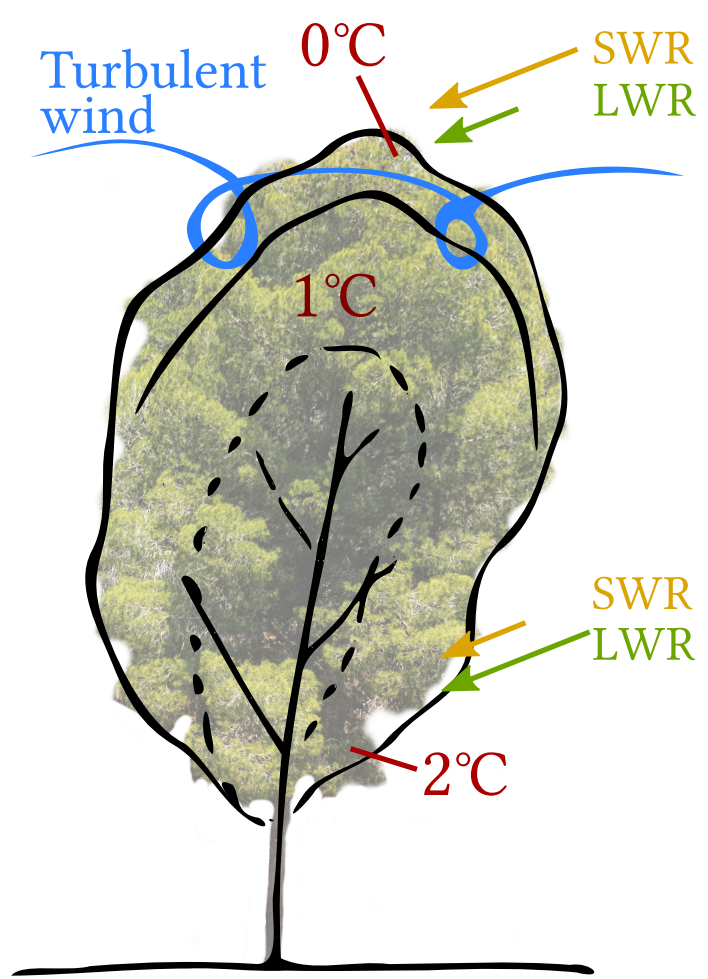

Fig. 4. Conceptual diagram of the distribution of $\Delta T_{\text {leaf-air }}$ within the canopy structure, indicating the observed $\Delta T_{\text {leaf-air }}$ values in the different layers in this study, in relations to the radiation input of short wave and long wave radiations (SWR and LWR) from the surroundings as well as air cooling effects through turbulent wind.

\section{Acknowledgements}

The authors are grateful to Tamir Dingjan for his help with needle-leaf identification in Python and for proof-reading, Huanhuan Wang for chlorophyll measurements, Irina Vishnevetsky for emissivity measurements of different materials and Revital Weic for her manual sampling of needle-leaf temperature.

This study was supported by by JNF-KKL (10-10- 832 920-19) and a research grant from the Yotam project 833 and the Weizmann Institute Sustainability and En- 834 ergy Research Initiative. The long-term operation 835 of the Yatir Forest Research Field Site is supported 836 by the Cathy Wills and Robert Lewis Program in ${ }_{837}$ Environmental Science. 
bioRxiv preprint doi: https://doi.org/10.1101/2021.02.01.429145; this version posted April 29, 2021. The copyright holder for this preprint (which was not certified by peer review) is the author/funder, who has granted bioRxiv a license to display the preprint in perpetuity. It is made available under aCC-BY-ND 4.0 International license.

\section{Author contributions}

The study was conceived by JM,ER and DY; JM developed the IR system, and carried out the measurements with the help of IO and FT; JM analysed the data under the guidance of ER and DY; JM,ER and DY contributed to the writing.

\section{Code and data availability}

The data that support the findings of this study are available from the corresponding author upon reasonable request. Software scripts developed for the analysis are openly available as follows:

- Script to analyse gas exchange chamber flux data: 'Branch-chamber-fluxes' at https://doi. org/10.5281/zenodo.4284487, reference (Muller and $\mathrm{Oz}, 2020)$

- Script to automatically trigger an infrared camera through a LAN interface: 'FLIR-A320control' at https://doi.org/10.5281/zenodo. 4088156, reference (Muller, 2020)

- Python script to extract raw temperature data from FLIR infrared images: 'IR-data-extraction' at https://doi.org/10.5281/zenodo.4104314, reference (Muller and Segev, 2020)

- Script to detect pine needles and reference plates in infrared images: 'Pine-needle-thermaldetection' at https://doi.org/10.5281/zenodo. 4284621, reference (Muller and Dingjan, 2020)

\section{References}

Allen, C. D., Macalady, A. K., Chenchouni, H., Bachelet, D., McDowell, N., Vennetier, M., Kitzberger, T., Rigling, A., Breshears, D. D., Hogg, E. H. T., Gonzalez, P., Fensham, R., Zhang, Z., Castro, J., Demidova, N., Lim, J.H., Allard, G., Running, S. W., Semerci, A., and Cobb, N. A global overview of drought and heat-induced tree mortality reveals emerging climate change risks for forests. Forest Ecology and Management, 259(4):660-684, February 2010. doi:10.1016/j.foreco.2009.09.001.
Allen, C. D., Breshears, D. D., and McDowell, N. 878 On underestimation of global vulnerability to tree 879 mortality and forest die-off from hotter drought in 880 the Anthropocene. Ecosphere, 6(8):art129, 2015. 881 doi:10.1890/ES15-00203.1.

Aubrecht, D. M., Helliker, B. R., Goulden, M. L., 883 Roberts, D. A., Still, C., and Richardson, A. D. 884 Continuous, long-term, high-frequency thermal 885 imaging of vegetation: Uncertainties and recom- 886 mended best practices. Agricultural and Forest 887 Meteorology, 228-229:315-326, November 2016. 888 doi:10.1016/j.agrformet.2016.07.017.

Baldocchi, D. and Ma, S. How will land use affect 890 air temperature in the surface boundary layer? 891 Lessons learned from a comparative study on the 892 energy balance of an oak savanna and annual grass- 893 land in California, USA. Tellus B: Chemical and 894 Physical Meteorology, 65(1):19994, December 2013. 895 doi:10.3402/tellusb.v65i0.19994.

Baldocchi, D. and Penuelas, J. The physics and ${ }_{897}$ ecology of mining carbon dioxide from the atmo- 898 sphere by ecosystems. Global Change Biology, 25899 (4):1191-1197, 2019. doi:10.1111/gcb.14559.

Banerjee, T., De Roo, F., and Mauder, M. Explaining 901 the convector effect in canopy turbulence by means 902 of large-eddy simulation. Hydrology and Earth 903 System Sciences (Online), 21(LA-UR-17-22651), 904 2017.

Birami, B., Gattmann, M., Heyer, A. G., Grote, 906 R., Arneth, A., and Ruehr, N. K. Heat Waves 907 Alter Carbon Allocation and Increase Mortality 908 of Aleppo Pine Under Dry Conditions. Fron- 909 tiers in Forests and Global Change, 1, 2018. 910 doi:10.3389/ffgc.2018.00008.

Bonan, G. B. Forests and Climate Change: For- 912 cings, Feedbacks, and the Climate Benefits of 913 Forests. Science, 320(5882):1444-1449, June 2008. 914 doi:10.1126/science.1155121.

Brugger, P., Banerjee, T., De Roo, F., Kröniger, K., 916 Qubaja, R., Rohatyn, S., Rotenberg, E., Tatarinov, 917 F., Yakir, D., Yang, F., and Mauder, M. Ef- 918 fect of Surface Heterogeneity on the Boundary- 919 Layer Height: A Case Study at a Semi-Arid 920 Forest. Boundary-Layer Meteorology, 169(2):233- 921 250, November 2018. doi:10.1007/s10546-018-0371- 922 5 .

Drake, J. E., Tjoelker, M. G., V\a arhammar, A., 924 Medlyn, B. E., Reich, P. B., Leigh, A., Pfautsch, S., 925 Blackman, C. J., López, R., and Aspinwall, M. J. 926 
bioRxiv preprint doi: https://doi.org/10.1101/2021.02.01.429145; this version posted April 29, 2021. The copyright holder for this preprint (which was not certified by peer review) is the author/funder, who has granted bioRxiv a license to display the preprint in perpetuity. It is made available under aCC-BY-ND 4.0 International license.

Trees tolerate an extreme heatwave via sustained transpirational cooling and increased leaf thermal tolerance. Global change biology, 2018.

Dusenge, M. E., Duarte, A. G., and Way, D. A. Plant carbon metabolism and climate change: elevated CO 2 and temperature impacts on photosynthesis, photorespiration and respiration. New Phytologist, 221(1):32-49, 2019.

Eder, F., De Roo, F., Rotenberg, E., Yakir, D., Schmid, H. P., and Mauder, M. Secondary circulations at a solitary forest surrounded by semi-arid shrubland and their impact on eddy-covariance measurements. Agricultural and Forest Meteorology, 211:115-127, 2015.

FLIR. FLIR A3xx series - User's manual. Publ. No. T559498 Rev. a547, FLIR, July 2011.

Fritschen, L. J. and Gay, L. W. Environmental Instrumentation. Springer Science \& Business Media, December 2012. ISBN 978-1-4612-6205-3.

Fuchs, M. Infrared measurement of canopy temperature and detection of plant water stress. Theoretical and Applied Climatology, 42(4):253-261, December 1990. doi:10.1007/BF00865986.

Gates, D. M. Leaf temperature and energy exchange. Archiv für Meteorologie, Geophysik und Bioklimatologie, Serie B, 12(2):321-336, October 1962. doi:10.1007/BF02315993.

Gates, D. M., Tibbals, E. C., and Kreith, F. Radiation and convection for ponderosa pine. American Journal of Botany, 52(1):66-71, 1965.

Geller, G. and Smith, W. Influence of leaf size, orientation, and arrangement on temperature and transpiration in three high-elevation, largeleafed herbs. Oecologia, 53(2):227-234, 1982. doi:10.1007/BF00545668.

Grace, J. and Wilson, J. The Boundary Layer over a Populus Leaf. Journal of Experimental Botany, 27 (2):231-241, April 1976. doi:10.1093/jxb/27.2.231.

Grace, J., Fasehun, F. E., and Dixon, M. Boundary layer conductance of the leaves of some tropical timber trees. Plant, Cell \& Environment, 3(6): 443-450, 1980. doi:https://doi.org/10.1111/13653040.ep11586917.

Grant, R. H. The mutual interference of spruce canopy structural elements. Agricultural and Forest Meteorology, 32(2):145-156, August 1984. doi:10.1016/0168-1923(84)90084-4.
Gutschick, V. P. Leaf Energy Balance: Basics, 974 and Modeling from Leaves to Canopies. In 975 Hikosaka, K., Niinemets, [U+FFFD], and Anten, 976 N. P., editors, Canopy Photosynthesis: From Ba- 977 sics to Applications, Advances in Photosynthesis 978 and Respiration, pages 23-58. Springer Nether- 979 lands, Dordrecht, 2016. ISBN 978-94-017-7291-4. 980 doi:10.1007/978-94-017-7291-4_2.

Hosgood, B., Jacquemoud, S., Andreoli, G., Ver- 982 debout, J., Pedrini, G., and Schmuck, G. Leaf 983 optical properties experiment 93 (LOPEX93). Re- 984 port EUR, 16095, 1995.

Idso, S. B., Jackson, R. D., Ehrler, W. L., and 986 Mitchell, S. T. A Method for Determination of 987 Infrared Emittance of Leaves. Ecology, 50(5):899- 988 902, 1969. doi:10.2307/1933705.

Incropera, F. P., DeWitt, D. P., Bergman, T. L., 990 and Lavine, A. S. Fundamentals of Heat and Mass 991 Transfer. John Wiley \& Sons, Hoboken, NJ, 6th edi- 992 tion edition, March 2006. ISBN 978-0-471-45728-2. 993

Jones, H. G. Application of Thermal Imaging and 994 Infrared Sensing in Plant Physiology and Eco- 995 physiology. In Advances in Botanical Research, 996 volume 41 of Incorporating Advances in Plant 997 Pathology, pages 107-163. Academic Press, Janu- 998 ary 2004. doi:10.1016/S0065-2296(04)41003-9.

999

Jones, H. G., Serraj, R., Loveys, B. R., Xiong, L., 1000 Wheaton, A., Price, A. H., Jones, H. G., Serraj, R., 1001 Loveys, B. R., Xiong, L., Wheaton, A., and Price, 1002 A. H. Thermal infrared imaging of crop canop- 1003 ies for the remote diagnosis and quantification of 1004 plant responses to water stress in the field. Func- 1005 tional Plant Biology, 36(11):978-989, November 1006 2009. doi:10.1071/FP09123.

1007

Kim, Y., Still, C., Hanson, C. V., Kwon, H., 1008 Greer, B. T., and Law, B. E. Canopy skin 1009 temperature variations in relation to climate, 1010 soil temperature, and carbon flux at a ponder- 1011 osa pine forest in central Oregon. Agricultural 1012 and Forest Meteorology, 226-227:161-173, October 1013 2016. doi:10.1016/j.agrformet.2016.06.001.

1014

Kim, Y., Still, C., Roberts, D. A., and Goulden, M. L. 1015 Thermal infrared imaging of conifer leaf temperat- 1016 ures: Comparison to thermocouple measurements 1017 and assessment of environmental influences. Agri- 1018 cultural and Forest Meteorology, 248:361-371, Janu- 1019 ary 2018. doi:10.1016/j.agrformet.2017.10.010. 
bioRxiv preprint doi: https://doi.org/10.1101/2021.02.01.429145; this version posted April 29, 2021. The copyright holder for this preprint (which was not certified by peer review) is the author/funder, who has granted bioRxiv a license to display the preprint in perpetuity. It is made available under aCC-BY-ND 4.0 International license.

Kimball, B. A. and Bernacchi, C. J. Evapotranspiration, Canopy Temperature, and Plant Water Relations. In Nösberger, J., Long, S. P., Norby, R. J., Stitt, M., Hendrey, G. R., and Blum, H., editors, Managed Ecosystems and CO2: Case Studies, Processes, and Perspectives, Ecological Studies, pages 311-324. Springer, Berlin, Heidelberg, 2006. ISBN 978-3-540-31237-6. doi:10.1007/3-540-31237-4_17.

Kirschbaum, M. U. F. and McMillan, A. M. S. Warming and Elevated CO2 Have Opposing Influences on Transpiration. Which is more Important? Current Forestry Reports, 4(2):51-71, June 2018. doi:10.1007/s40725-018-0073-8.

Kool, D., Kustas, W. P., Ben-Gal, A., Lazarovitch, N., Heitman, J. L., Sauer, T. J., and Agam, N. Energy and evapotranspiration partitioning in a desert vineyard. Agricultural and Forest Meteorology, 218:277-287, March 2016. doi:10.1016/j.agrformet.2016.01.002.

Kröniger, K., De Roo, F., Brugger, P., Huq, S., Banerjee, T., Zinsser, J., Rotenberg, E., Yakir, D., Rohatyn, S., and Mauder, M. Effect of Secondary Circulations on the Surface-Atmosphere Exchange of Energy at an Isolated Semi-arid Forest. Boundary-Layer Meteorology, 169(2):209232, November 2018. doi:10.1007/s10546-018-03706.

Kurzeja, R. Accurate Temperature Measurements in a Naturally-Aspirated Radiation Shield. BoundaryLayer Meteorology, 134(1):181, November 2009. doi:10.1007/s10546-009-9430-2.

Kustas, W. P. and Norman, J. M. Evaluation of soil and vegetation heat flux predictions using a simple two-source model with radiometric temperatures for partial canopy cover. Agricultural and Forest Meteorology, 94(1):13-29, April 1999. doi:10.1016/S0168-1923(99)00005-2.

Lancaster, L. T. and Humphreys, A. M. Global variation in the thermal tolerances of plants. Proceedings of the National Academy of Sciences, 117(24):13580-13587, June 2020. doi:10.1073/pnas.1918162117.

Landsberg, J. J. and Thom, A. S. Aerodynamic properties of a plant of complex structure. Quarterly Journal of the Royal Meteorological Society, 97(414):565-570, 1971. doi:https://doi.org/10.1002/qj.49709741418.

Lapidot, O., Ignat, T., Rud, R., Rog, I., Alchanatis, V., and Klein, T. Use of thermal imaging to detect evaporative cooling in coniferous and broadleaved 1070 tree species of the Mediterranean maquis. Agricul- 1071 tural and Forest Meteorology, 271:285-294, June 1072 2019. doi:10.1016/j.agrformet.2019.02.014.

Leakey, A. D., Uribelarrea, M., Ainsworth, E. A., 1074 Naidu, S. L., Rogers, A., Ort, D. R., and Long, 1075 S. P. Photosynthesis, productivity, and yield of 1076 maize are not affected by open-air elevation of CO2 1077 concentration in the absence of drought. Plant 1078 physiology, 140(2):779-790, 2006.

Leigh, A., Sevanto, S., Ball, M. C., Close, J. D., Ells- 1080 worth, D. S., Knight, C. A., Nicotra, A. B., and Vo- 1081 gel, S. Do thick leaves avoid thermal damage in crit- 1082 ically low wind speeds? New Phytologist, 194(2): 1083 477-487, 2012. doi:https://doi.org/10.1111/j.1469- 1084 8137.2012.04058.x.

Leigh, A., Sevanto, S., Close, J. D., and Nicotra, 1086 A. B. The influence of leaf size and shape on 1087 leaf thermal dynamics: does theory hold up under 1088 natural conditions? Plant, cell \& environment, 401089 (2):237-248, 2017.

Leuzinger, S. and Körner, C. Tree species di- 1091 versity affects canopy leaf temperatures in a 1092 mature temperate forest. Agricultural and 1093 Forest Meteorology, 146(1):29-37, September 2007. 1094 doi:10.1016/j.agrformet.2007.05.007.

1095

Leuzinger, S., Vogt, R., and Körner, C. Tree surface 1096 temperature in an urban environment. Agricul- 1097 tural and Forest Meteorology, 150(1):56-62, Janu- 1098 ary 2010. doi:10.1016/j.agrformet.2009.08.006.

1099

Liu, S., Lu, L., Mao, D., and Jia, L. Evaluating 1100 parameterizations of aerodynamic resistance to 1101 heat transfer using field measurements. Hydrology 1102 and Earth System Sciences Discussions, 11(2):769- 1103 783, 2007.

Long, S. P., Humphries, S., and Falkowski, P. G. Pho- 1105 toinhibition of photosynthesis in nature. Annual 1106 review of plant biology, 45(1):633-662, 1994.

Long, S. P., Ainsworth, E. A., Leakey, A. 1108 D. B., Nösberger, J., and Ort, D. R. ${ }_{1109}$ Food for Thought: Lower-Than-Expected Crop 1110 Yield Stimulation with Rising CO2 Concentra- 1111 tions. Science, 312(5782):1918-1921, June 2006. 1112 doi:10.1126/science.1114722.

1113

Maimaitijiang, M., Sagan, V., Sidike, P., Hart- 1114 ling, S., Esposito, F., and Fritschi, F. B. Soy- 1115 bean yield prediction from UAV using multimodal 1116 
bioRxiv preprint doi: https://doi.org/10.1101/2021.02.01.429145; this version posted April 29, 2021. The copyright holder for this preprint (which was not certified by peer review) is the author/funder, who has granted bioRxiv a license to display the preprint in perpetuity. It is made available under aCC-BY-ND 4.0 International license.

data fusion and deep learning. Remote Sensing of Environment, 237:111599, February 2020. doi:10.1016/j.rse.2019.111599.

Maseyk, K. S. Ecophysiological and phenological aspects of Pinus halepensis in an aridMediterranean environment. Ph.D., The Weizmann Institute of Science (Israel), Israel, 2006. URL https://search.proquest.com/docview/ 304955792/citation/84F5442BDD884B15PQ/1.

Maseyk, K. S., Lin, T., Rotenberg, E., Grünzweig, J. M., Schwartz, A., and Yakir, D. Physiology-phenology interactions in a productive semi-arid pine forest. New Phytologist, 178(3): 603-616, 2008. doi:https://doi.org/10.1111/j.14698137.2008.02391.x.

McMahon, T. A., Peel, M. C., Lowe, L., Srikanthan, R., and McVicar, T. R. Estimating actual, potential, reference crop and pan evaporation using standard meteorological data: a pragmatic synthesis. Hydrol. Earth Syst. Sci, 17(4):1331-1363, 2013.

Michaletz, S. T. and Johnson, E. A. Foliage influences forced convection heat transfer in conifer branches and buds. New Phytologist, 170(1):87-98, 2006. doi:10.1111/j.1469-8137.2006.01661.x.

Michaletz, S. T., Weiser, M. D., Zhou, J., Kaspari, M., Helliker, B. R., and Enquist, B. J. Plant Thermoregulation: Energetics, Trait-Environment Interactions, and Carbon Economics. Trends in Ecology Es Evolution, 30(12):714-724, December 2015. doi:10.1016/j.tree.2015.09.006.

Michaletz, S. T., Weiser, M. D., McDowell, N. G., Zhou, J., Kaspari, M., Helliker, B. R., and Enquist, B. J. The energetic and carbon economic origins of leaf thermoregulation. Nature Plants, 2(9):1-9, August 2016. doi:10.1038/nplants.2016.129.

Monteith, J. L. Principles of environmental physics Edward Arnold. London, $214 p, 1973$.

Muller, J. D. FLIR-A320-control: Tool to remotely focus and trigger a FLIR A320 infrared camera, October 2020. URL https://zenodo.org/record/ 4088156.

Muller, J. D. and Dingjan, T. Pine-needle-thermaldetection: Tool to detect pine needles in thermal images, November 2020. URL https://zenodo.org/ record $/ 4284621$.
Muller, J. D. and Oz, I. Branch-chamber-fluxes: 1163 Branch-chamber-fluxes, November 2020. URL ${ }_{1164}$ https://zenodo.org/record/4284487.

Muller, J. D. and Segev, L. IR-data-extraction: Tool 1166 to extract raw temperature data from FLIR R- 1167 jpegs, October 2020. URL https://zenodo.org/ 1168 record $/ 4104314$.

Muller, J. D., Rotenberg, E., Tatarinov, F., Vish- 1170 nevetsky, I., Dingjan, T., Kribus, A., and Yakir, D. 1171 Dual reference method for high precision infrared 1172 measurement of leaf surface temperature under 1173 field conditions. bioRxiv, page 2021.04.25.440729, ${ }_{1174}$ April 2021. doi:10.1101/2021.04.25.440729.

Neriah, A. B., Assouline, S., Shavit, U., and 1176 Weisbrod, N. Impact of ambient conditions 1177 on evaporation from porous media. $W a-1178$ ter Resources Research, 50(8):6696-6712, 2014. 1179 doi:https://doi.org/10.1002/2014WR015523.

O'sullivan, O. S., Heskel, M. A., Reich, P. B., 1181 Tjoelker, M. G., Weerasinghe, L. K., Penillard, ${ }_{1182}$ A., Zhu, L., Egerton, J. J. G., Bloomfield, K. J., 1183 Creek, D., Bahar, N. H. A., Griffin, K. L., Hurry, 1184 V., Meir, P., Turnbull, M. H., and Atkin, O. K. ${ }_{1185}$ Thermal limits of leaf metabolism across biomes. 1186 Global Change Biology, 23(1):209-223, January 1187 2017. doi:10.1111/gcb.13477.

Pau, S., Detto, M., Kim, Y., and Still, C. 1189 Tropical forest temperature thresholds for gross 1190 primary productivity. Ecosphere, 9(7):e02311, 1191 2018. doi:https://doi.org/10.1002/ecs2.2311. 1192

Peel, M. C., Finlayson, B. L., and McMahon, T. A. ${ }_{1193}$ Updated world map of the Köppen-Geiger cli- 1194 mate classification. Hydrology and Earth Sys- 1195 tem Sciences, 11(5):1633-1644, October 2007. 1196 doi:10.5194/hess-11-1633-2007.

Preisler, Y. Water-use strategies leading to resilience 1198 of pine trees to global climatic change. PhD Thesis, 1199 Hebrew University of Jerusalem, Rehovot, Israel, 1200 December 2019.

1201

Qubaja, R., Grünzweig, J. M., Rotenberg, E., and 1202 Yakir, D. Evidence for large carbon sink and long 1203 residence time in semiarid forests based on 15 year 1204 flux and inventory records. Global Change Biology, 1205 2019. doi:10.1111/gcb.14927.

Qubaja, R., Amer, M., Tatarinov, F., Rotenberg, E., 1207 Preisler, Y., Sprintsin, M., and Yakir, D. Parti- 1208 tioning evapotranspiration and its long-term evolu- 1209 tion in a dry pine forest using measurement-based 1210 
bioRxiv preprint doi: https://doi.org/10.1101/2021.02.01.429145; this version posted April 29, 2021. The copyright holder for this preprint (which was not certified by peer review) is the author/funder, who has granted bioRxiv a license to display the preprint in perpetuity. It is made available under aCC-BY-ND 4.0 International license.

estimates of soil evaporation. Agricultural and Forest Meteorology, 281:107831, February 2020. doi:10.1016/j.agrformet.2019.107831.

Richardson, A. D., Aubrecht, D. M., Basler, D., Hufkens, K., Muir, C. D., and Hanssen, L. Developmental changes in the reflectance spectra of temperate deciduous tree leaves, and implications for thermal emissivity and leaf temperature. New Phytologist, n/a(n/a), 2020. doi:10.1111/nph.16909.

Rotenberg, E. and Yakir, D. Contribution of Semi-Arid Forests to the Climate System. Science, 327(5964):451-454, January 2010. doi:10.1126/science.1179998.

Rotenberg, E. and Yakir, D. Distinct patterns of changes in surface energy budget associated with forestation in the semiarid region. Global Change Biology, 17(4):1536-1548, 2011. doi:10.1111/j.13652486.2010.02320.x.

Schuepp, P. H. Tansley Review No. 59. Leaf Boundary Layers. The New Phytologist, 125(3):477-507, 1993.

Schymanski, S. J. and Or, D. Wind increases leaf water use efficiency. Plant, Cell \& Environment, 39(7):1448-1459, 2016. doi:10.1111/pce.12700.

Schymanski, S. J., Or, D., and Zwieniecki, M. Stomatal Control and Leaf Thermal and Hydraulic Capacitances under Rapid Environmental Fluctuations. PLOS ONE, 8(1):e54231, January 2013. doi:10.1371/journal.pone.0054231.

Siebert, S., Ewert, F., Rezaei, E. E., Kage, H., and Graß, R. Impact of heat stress on crop yield-on the importance of considering canopy temperature. Environmental Research Letters, 9(4):044012, April 2014. doi:10.1088/1748-9326/9/4/044012.

Smith, W. K. Temperatures of Desert Plants: Another Perspective on the Adaptability of Leaf Size. Science, 201(4356):614-616, August 1978. doi:10.1126/science.201.4356.614.

Smith, W. K. and Carter, G. A. Shoot structural effects on needle temperatures and photosynthesis in conifers. American Journal of Botany, 75(4): 496-500, 1988.

Smith, W. K., Dannenberg, M. P., Yan, D., Herrmann, S., Barnes, M. L., Barron-Gafford, G. A., Biederman, J. A., Ferrenberg, S., Fox, A. M., Hudson, A., Knowles, J. F., MacBean, N., Moore, D.
J. P., Nagler, P. L., Reed, S. C., Rutherford, W. A., 1258 Scott, R. L., Wang, X., and Yang, J. Remote sens- 1259 ing of dryland ecosystem structure and function: 1260 Progress, challenges, and opportunities. Remote 1261 Sensing of Environment, 233:111401, November 1262 2019. doi:10.1016/j.rse.2019.111401.

Song, Q.-H., Deng, Y., Zhang, Y. P., Deng, X.-B., 1264 Lin, Y.-X., Zhou, L.-G., Fei, X.-H., Sha, L.-Q., Liu, 1265 Y.-T., Zhou, W.-J., and Gao, J.-B. Comparison of 1266 infrared canopy temperature in a rubber plantation 1267 and tropical rain forest. International Journal of 1268 Biometeorology, 61(10):1885-1892, October 2017. 1269 doi:10.1007/s00484-017-1375-4.

1270

Still, C., Powell, R., Aubrecht, D., Kim, Y., Helliker, 1271 B., Roberts, D., Richardson, A. D., and Goulden, 1272 M. Thermal imaging in plant and ecosystem eco- 1273 logy: applications and challenges. Ecosphere, 101274 (6), 2019 .

1275

Still, C., Rastogi, B., Page, G. F. M., Griffith, D. M., 1276 Sibley, A., Schulze, M., Hawkins, L., Pau, S., 1277 Detto, M., and Helliker, B. R. Imaging canopy 1278 temperature: shedding (thermal) light on ecosys- 1279 tem processes. New Phytologist, n/a(n/a), 2021. 1280 doi:10.1111/nph.17321.

Tatarinov, F., Rotenberg, E., Maseyk, K., Ogée, 1282 J., Klein, T., and Yakir, D. Resilience to sea- 1283 sonal heat wave episodes in a Mediterranean pine 1284 forest. New Phytologist, 210(2):485-496, April 1285 2016. doi:10.1111/nph.13791.

1286

Tattersall, G. Thermimage, v.4.1.0, December 2019. ${ }_{1287}$ URL https://zenodo.org/record/3590036.

1288

Taylor, S. E. Optimal Leaf Form. In Gates, D. M. and 1289 Schmerl, R. B., editors, Perspectives of Biophysical 1290 Ecology, Ecological Studies, pages 73-86. Springer, 1291 Berlin, Heidelberg, 1975. ISBN 978-3-642-87810-7. 1292 doi:10.1007/978-3-642-87810-7_5.

Tibbals, E. C., Carr, E. K., Gates, D. M., and Kreith, 1294 F. Radiation and convection in conifers. American 1295 Journal of Botany, 51(5):529-538, 1964.

1296

Urban, J., Ingwers, M. W., McGuire, M. A., and ${ }_{1297}$ Teskey, R. O. Increase in leaf temperature 1298 opens stomata and decouples net photosynthesis 1299 from stomatal conductance in Pinus taeda and 1300 Populus deltoides x nigra. Journal of Exper- 1301 imental Botany, 68(7):1757-1767, March 2017. 1302 doi:10.1093/jxb/erx052.

1303

Verma, S. B. Aerodynamic resistances to transfers 1304 of heat, mass and momentum. Estimation of areal 1305 evapotranspiration, 177:13-20, 1989. 
bioRxiv preprint doi: https://doi.org/10.1101/2021.02.01.429145; this version posted April 29, 2021. The copyright holder for this preprint (which was not certified by peer review) is the author/funder, who has granted bioRxiv a license to display the preprint in perpetuity. It is

Virtanen, P., Gommers, R., Oliphant, T. E., Haberland, M., Reddy, T., Cournapeau, D., Burovski, E., Peterson, P., Weckesser, W., Bright, J., van der Walt, S. J., Brett, M., Wilson, J., Millman, K. J., Mayorov, N., Nelson, A. R. J., Jones, E., Kern, R., Larson, E., Carey, C. J., Polat, I., Feng, Y., Moore, E. W., VanderPlas, J., Laxalde, D., Perktold, J., Cimrman, R., Henriksen, I., Quintero, E. A., Harris, C. R., Archibald, A. M., Ribeiro, A. H., Pedregosa, F., and van Mulbregt, P. SciPy 1.0: fundamental algorithms for scientific computing in Python. Nature Methods, 17(3):261-272, March 2020. doi:10.1038/s41592-019-0686-2.

Vishnevetsky, I., Rotenberg, E., Kribus, A., and Yakir, D. Method for accurate measurement of infrared emissivity for opaque low-reflectance materials. Applied Optics, 58(17):4599-4609, 2019.

Werner, C., Correia, O., Beyschlag, W., Werner, C., Correia, O., and Beyschlag, W. Characteristic patterns of chronic and dynamic photoinhibition of different functional groups in a Mediterranean ecosystem, Characteristic patterns of chronic and dynamic photoinhibition of different functional groups in a Mediterranean ecosystem. Functional Plant Biology, Functional Plant Biology, 29, 29(8, 8):999, 999-1011, 1011, August 2002. doi:10.1071/PP01143, 10.1071/PP01143.

Wulfmeyer, V., Branch, O., Warrach-Sagi, K., Bauer, H.-S., Schwitalla, T., and Becker, K. The Impact of Plantations on Weather and Climate in Coastal Desert Regions. Journal of Applied Meteorology and Climatology, 53(5):1143-1169, January 2014. doi:10.1175/JAMC-D-13-0208.1.

Yi, K., Smith, J. W., Jablonski, A. D., Tatham, E. A., Scanlon, T. M., Lerdau, M. T., Novick, K. A., and Yang, X. High Heterogeneity in Canopy Temperature Among Co-occurring Tree Species in a Temperate Forest. Journal of Geophysical Research: Biogeosciences, 125(12):e2020JG005892, 2020. doi:https://doi.org/10.1029/2020JG005892.

Zhang, L., Niu, Y., Zhang, H., Han, W., Li, G., Tang, J., and Peng, X. Maize Canopy Temperature Extracted From UAV Thermal and RGB Imagery and Its Application in Water Stress Monitoring. Frontiers in Plant Science, 10, 2019. doi:10.3389/fpls.2019.01270. 